\title{
Identifying and Overcoming Barriers to Collaborative Sustainable Water Governance in Remote Australian Indigenous Communities
}

\author{
Melissa Jackson ${ }^{1,2, *}$, Rodney A. Stewart ${ }^{1,2}$ (D) and Cara D. Beal ${ }^{2,3, *(D)}$ \\ 1 School of Engineering and Built Environment, Griffith University, Gold Coast 4222, QLD, Australia; \\ r.stewart@griffith.edu.au \\ 2 Cities Research Institute, Griffith University, Nathan 4111, QLD, Australia \\ 3 School of Medicine, Griffith University, Nathan 4111, QLD, Australia \\ * Correspondence: melissa.jackson@griffithuni.edu.au (M.J.); c.beal@griffith.edu.au (C.D.B.); \\ Tel.: +61-435-207-578 (M.J.); +61-7-3725-9215 (C.D.B.)
}

Received: 13 September 2019; Accepted: 9 November 2019; Published: 17 November 2019

\begin{abstract}
Collaboration between government agencies and communities for sustainable water governance in remote Indigenous communities is espoused as a means to contribute to more equitable, robust, and long-term decision-making and to ensure that water services contribute to broader considerations of physical, social, and economic prosperity. In Australia, the uptake of collaborative water governance in remote Aboriginal and Torres Strait Island contexts has been slow and few examples exist from which to inform policy and practice. This study identifies barriers to uptake of collaborative sustainable water governance, drawing from qualitative interviews with water practitioners working in remote Indigenous Australia and analysis of key project documentation. Thematic analysis revealed discrete barriers across five key categories: (1) governance arrangements, (2) economic and financial, (3) capacity and skills, (4) data and information, and (5) cultural values and norms, with many barriers identified, unique to the remote Indigenous Australian context. The paper provides insights into how to address these barriers strategically to create transformative and sustainable change for Indigenous communities. The results contribute to the greater body of knowledge on sustainable and collaborative water governance, and they are of relevance for broader water management, policy, and research.
\end{abstract}

Keywords: water; Indigenous communities; sustainable governance; management; collaboration; barriers

\section{Introduction}

Access to a safe, secure supply of fresh water is fundamental to the health, wellbeing, and prosperity of communities, and a foundation for sustainable development across regions and nations [1]. In remote areas, water resources can be seasonally scarce, and small populations are spread over large areas, making management for long-term sustainability challenging. Indigenous peoples often have strong connections and presence in remote communities due to centuries and millennia of continual connection to specific territories and resources [2-7]. However, Indigenous peoples are also overrepresented among the world's poorest and most marginalized and, therefore, consideration of water sustainability must be cognizant of this socio-economic context [3].

Internationally, poor water and sanitation services in Indigenous communities are linked to inappropriate institutionalization and poor functionality stemming from "ineffective dialogue, insufficient inclusion of concerned groups, and lack of local knowledge and cultural perceptions linked to water and sanitation" [7]. These issues are relevant in remote Australia, where it is described as 
"a crisis of disengagement, ineffective government arrangements, and national indifference", and, despite good intentions, nearly all current government policies, funding mechanisms, and programs are inadequate or demonstrably failing in remote Indigenous contexts [8].

The traditional Western management paradigm, which dominated water management in recent decades, considers water as an asset or resource to be managed, employing a narrow focus on engineering and infrastructure aspects, often at the expense of the social and environmental considerations that are a critical part of water systems [9-11]. Within this framework, scientific and "expert" knowledge is privileged over other forms of knowledge [12-14], and, until very recently, there was little inclusion of Indigenous perspectives in the management of water resources [2] or significant Indigenous representation at higher levels of governance [15-17]. As with many aspects of governance, Indigenous voices are systemically marginalized. The effectiveness of these technocratic "command and control" [18] approaches to address complex sustainability challenges, thus, came under scrutiny $[10,11]$, and there is now wide recognition of the need to transform the way water is governed to facilitate collaborative action across actors [19].

Collaboration refers to cooperative management of water (and other common pool resources) by diverse actors with an interest in the outcomes of those decisions [19-21]. This involves a greater level of power sharing and devolution of planning processes and decision-making from government or other authorities to local communities. Although the extent of decision-making power held by public and private actors (e.g., the state and a local community) can vary significantly [19,22,23], collaborative governance can better address both sustainability and representation issues [3] bringing informal and formal mechanisms together as part of a systemic approach to community water governance [13-15,18,20,22-36].

The potential benefits of collaborative water governance and management in remote Indigenous communities include improved quality of management and durability and acceptance of decisions by those involved [16,18,32-34]. The vulnerability of small and remote Indigenous communities can also be reduced by building skills and capacity of local communities to manage and control water systems, and to take a whole cycle of water planning approach at the community level [35]. However, despite efforts at policy reform to facilitate governments working more effectively with Aboriginal and Torres Strait Island communities in Australia [36], examples of collaborative water governance are slow to emerge [22], and the majority of water decisions continue to be made by government agencies, with little recourse to community views or input from Indigenous community members [16,21,37,38]. Furthermore, very little systematic research on sustainable collaborative water governance, particularly in Indigenous community contexts, is available from which to determine the causes of low adoption, implementation, or success factors [21,39-41].

Uncertainty, therefore, remains about how to effectively implement collaborative water governance processes for sustainable transformation across remote Indigenous communities in practice. Given this uncertainty, we aimed to explore barriers in more detail by conducting interviews with those involved in governance of potable water supplies in remote Indigenous communities. This paper, therefore, presents a qualitative study of barriers to transformative and collaborative water governance across remote Aboriginal and Torres Strait Island communities in Australia from the perspective of water managers and practitioners. The study forms part of a larger research collaboration led by the authors in conjunction with the Australian water industry and academic partners that aimed to identify effective community-based strategies to improve sustainability and security of water supplies in remote Aboriginal and Torres Strait Island communities. This study addresses the following question: What factors prevent uptake and implementation of sustainable collaborative potable water governance processes for transformative outcomes in remote Indigenous communities? Data were drawn from interviews with professionals involved in the practice of community water management and governance, including service providers, government organizations, non-government organizations, contractors, and researchers working in remote Australia, and supplemented with a document review and analysis 
of remote community sustainable potable water governance initiatives. The research also considered areas for improvement and opportunities to shift the management status quo.

This paper is the first to present a combination of both theoretical and empirical insights into the key factors challenging transformative and collaborative potable water governance in remote and Indigenous Australian communities. The research is contextualized in space and time, and insights are drawn directly from those working on the ground in remote Australia; it, therefore, provides an important snapshot of the state of water governance and contributes to the body of water governance literature. The findings are, thus, of relevance to policy and decision-making in Indigenous Australia and the Australian water sector. However, with similar scenarios for water security and sustainability and the broader context of Indigenous rights and recognition being faced in communities globally, the research is also relevant for researchers, managers, and policymakers for community-scale sustainable water governance beyond the Australian context.

The paper is structured as follows: firstly, an overview of the context for water governance activities and arrangements in remote Australia is provided. This is followed by a brief review of barriers identified in the broader literature that relate to collaborative water governance (Section 2). This is followed by a description of the methods used to recruit water managers, researchers, and other key actors and decision-makers and to qualitatively explore their experiences with sustainable and collaborative water activities in remote Indigenous Australia (Section 3). Results of the barrier analysis are presented in Section 4, followed by a discussion of implications for practice (Section 5). The paper concludes by identifying opportunities addressing the barriers identified and by more broadly reflecting on implications for sustainable water governance.

\section{Context for Collaborative Sustainable Water Governance in Remote Indigenous Australia}

Over one-fifth of Australia's Aboriginal and Torres Strait Island populations live in remote regions of Australia in over 1100 communities of diverse sizes, cultures, and languages [42,43]. Water service provision in these areas is challenged by small, highly dispersed populations across large geographic areas, with comparatively fewer human and financial resources available [44,45], leading to poor economies of scale $[33,46]$. Harsh environmental conditions, and an absence of planned maintenance lead to high rates of corrosion of infrastructure and equipment, breakdowns, and failures, and, together with a reliance on diesel generated electricity, they contribute to higher running costs and a shorter asset lifespan [33,47]. High and increasing residential water demand [32,35], driven by a range of cultural, health, amenity, and social factors [39], also contribute to unsustainable and costly water supply-in some regions up to 10 times the cost to supply in urban areas [48]. Small-scale water systems operating in remote communities are more vulnerable to breakdown and contamination, and they often experience greater administrative, managerial, or resourcing challenges than larger water supply systems [49]. This complex operational and management environment leads to health, safety, and environmental implications [47]. Residents of remote communities not only experience limited access to services [1,50], but they are also exposed to a greater risk of pathogens and other contaminants than their urban counterparts, with ongoing boil water alerts, and severe outbreaks of water quality-related illness not uncommon [45,51]. Communities can, therefore, be vulnerable, particularly in the context of increasingly unpredictable and extreme weather, such as cyclones and droughts, associated with climate change [52].

The nature of water governance has important implications for sustainability of communities and water systems. As previously introduced, traditional water management focuses on the more easily controlled technical aspects of the water system, including water supply development and infrastructure, water services delivery, and regulation of water uses [10,11]; however, such solutions are often short-term and do not persist past the life of the infrastructure [20,33]. Although improvements in access to treated drinking water and sanitation were achieved in remote Australia through this approach [53], over a decade of policies and programs aiming to close the gap between Indigenous 
and non-Indigenous Australians made slow progress [54], and Aboriginal and Torres Strait Islander peoples remain the most disadvantaged of any Indigenous people in developed nations $[4,18,55,56]$.

Unlike simple problems where engineering or technical solutions can be implemented at a single site, managing for sustainable, secure, and safe supplies of water over the long term is multi-faceted, requiring consideration of complex interactions between the physical resources, infrastructure, institutions, and end users, often across governance and cultural boundaries [20,57,58]. Collaboration and cooperation between government and communities, therefore, comes to the fore as critical to progressing sustainable development of rural community water supplies and transformation of remote communities $[17,19,21,22,24-26,59]$. Inclusivity of diverse actors and establishing a shared understanding of issues and possible solutions between those actors are the foundational premise of collaboration [24,60-64]. Drawing from diverse sources and types of knowledge $[19,23,65,66]$, collaborative processes can encourage social learning amongst key stakeholders, which is important to learn from past programs and mistakes $[13,15,37,67]$.

Collaborative processes are particularly of interest in Indigenous communities, for the important flow-on effects that can be generated, including improved health and wellbeing, education, upskilling and livelihood opportunities, connections to regional economies, keeping young people in local regions, and reducing reliance on outsiders $[2,5,35,68]$. However, there is often little or no precedent for cooperation across actors, and lessons from both theory and practice indicate that collaborative efforts for sustainable water outcomes are difficult to initiate and sustain $[19,22]$. This is often because ideal conditions are very rarely in place for genuine collaboration [14,20]. Innes et al. (2007) [20] (p. 199) identified these conditions to include a focus on a practical, shared task, inclusion of all interests, self-organization rather than externally controlled, high-quality, agreed-upon information from many sources used as a basis for decisions, participants engaging in productive dialogue, encouraging creative thinking and challenges to the status quo, and decisions made only when there is overwhelming support.

Many remote water service providers, however, are under-resourced and have limited capacity to undertake processes outside their legislated remit. The risk in this context is that efforts at government-led collaboration may default to shallow participation that incorporates Indigenous people into state institutions rather than sharing power equitably [15]. Such efforts do little to recognize Indigenous self-determination objectives and can do more harm than good where pre-existing tension and mistrust in Indigenous-government relations is present [69]. Careful design, planning, and implementation of sustainable water processes are, therefore, critical to avoid co-option and a breakdown of trust amongst key actors $[15,20]$.

\subsection{Key Actors and Activities in Water Governance in Remote Indigenous Australia}

A range of actors and activities operate in relation to water services in remote Australia, with differences in responsibility for water occurring across jurisdictions and for communities of different sizes. Understanding these actors, their responsibilities, and key activities is important for understanding where and how barriers might challenge more sustainable, collaborative processes. Small communities are managed by local Aboriginal councils or resource centers (for very small outstations). For larger communities across the Northern Territory (NT), South Australia (SA), and Western Australia (WA), water utilities generally have responsibility for water supply and management [70]. However, governing the safe and sustainable supply of water to remote communities involves actors beyond those responsible for management. In most communities, water supply management is shared between residents (some employed as essential service officers) who carry out the day-to-day operation of the supply, and service providers responsible for larger maintenance tasks. In larger communities, other professionals (health, engineers, hydrogeologists) can be involved in decisions about risk management [70]. Figure 1 shows the range of actors that interact at different levels around water governance for remote Indigenous communities and examples of the activities undertaken at those levels. 


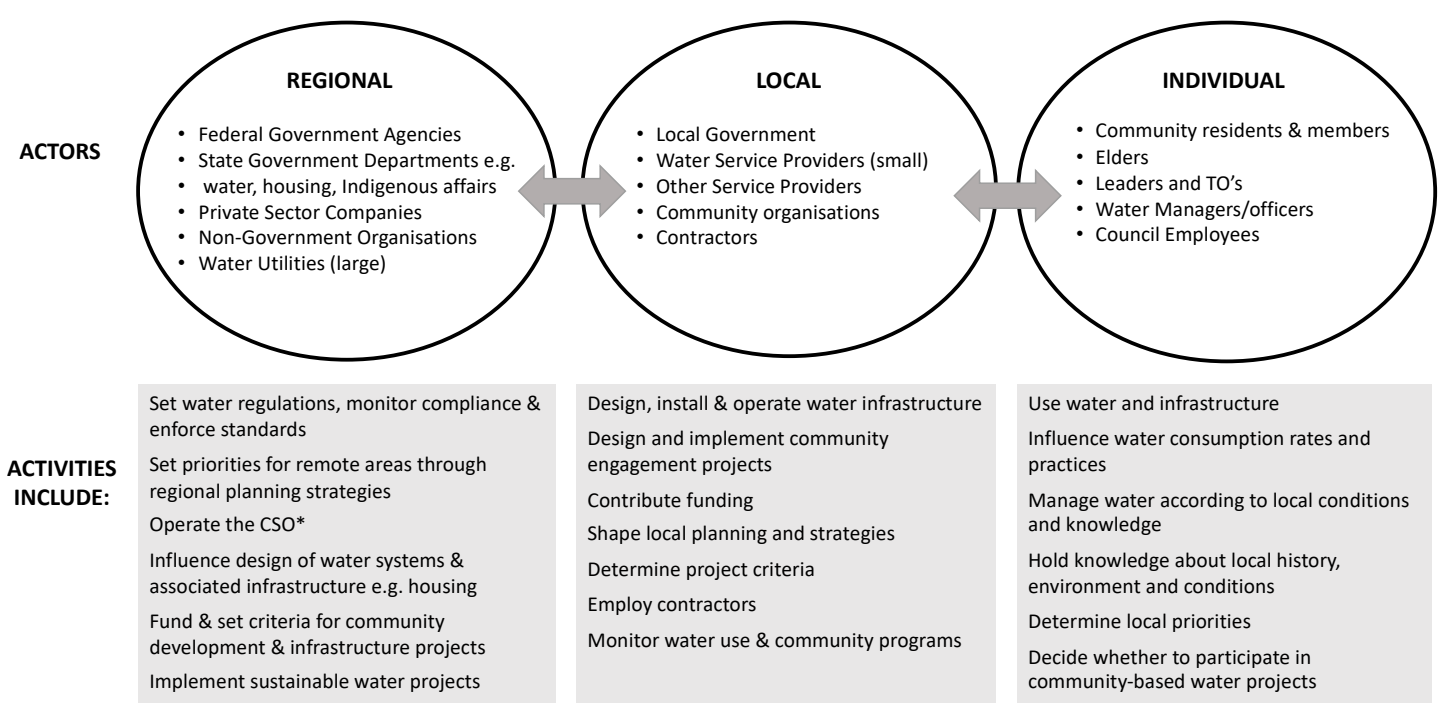

Figure 1. Actors and actions that influence the implementation of collaborative water management in remote Australia (adapted from Vogl et al., 2017 [57]). CSO-community service obligation, a taxpayer funded subsidy to provide affordability equity of services such as electricity and water to remote and rural areas; TO-Traditional Owner, a common title designated to descendants of a tribe that occupied a particular area prior to European settlement of Australia.

Actors such as state and Commonwealth government agencies set the policy environment in which water operators and consumers function and are the key source of funding for water infrastructure and community projects in remote Indigenous communities [21,70]. Non-government organizations and the private sector often are involved as partners or contractors to governments and utilities. Local governments generally have a strong presence in communities, and they are responsible for much infrastructure and maintenance; this includes water in some states (Queensland (QLD) and New South Wales (NSW)). Health centers, employment agencies, schools, and the police also play key roles in remote community life, and they influence water management through their operational demand for water, as well as interaction with residents. Residents themselves have control over how local infrastructure is used and in influencing family, households, and neighbors. While actors and activities operate primarily at a particular level, there is fluidity and movement across levels, and barriers (as well as enablers) can occur at each level or within the interactions between them.

\subsection{Challenges to Collaborative Water Governance in Remote Indigenous Australia Identified in the Literature}

Although sector specific research is lacking [71], a range of peer-reviewed research considered the challenges that are faced in achieving sustainable and collaborative water governance and management. Barriers presented in Table 1 were identified from a review of peer-reviewed studies that encompassed one or a combination of the following foci: sustainable water management, collaborative water management, water management in Indigenous contexts or water management in remote Australia, and engaging Indigenous Australians in community programs. 
Table 1. Barriers identified in peer-reviewed literature to sustainable, collaborative water management and engagement of Indigenous peoples.

\begin{tabular}{|c|c|c|c|c|c|c|}
\hline Study Focus & $\begin{array}{l}\text { Sustainable } \\
\text { Potable Water }\end{array}$ & Remote & Indigenous & $\begin{array}{c}\text { Collaboration and } \\
\text { Engagement }\end{array}$ & Barriers Identified & Reference \\
\hline $\begin{array}{l}\text { a) Institutional barriers to } \\
\text { SUWM Australia }\end{array}$ & $\checkmark$ & & & & $\begin{array}{l}\text { Socio-institutional rather than technical barriers: inter-organizational } \\
\text { capacity; external rules and incentives }\end{array}$ & {$[72]^{*}$} \\
\hline $\begin{array}{l}\text { b) Barriers to co-governance for } \\
\text { SUWM Australia }\end{array}$ & $\checkmark$ & & & $\checkmark$ & $\begin{array}{l}\text { Capacity; technocratic outlook; partner fatigue; lack of community } \\
\text { interest; limited representation }\end{array}$ & [22]^ \\
\hline c) Cooperative water management & $\checkmark$ & & $\checkmark$ & $\checkmark$ & $\begin{array}{l}\text { Inappropriate institutions; insufficient dialogue and inclusion of } \\
\text { local knowledge }\end{array}$ & {$[7]+$} \\
\hline $\begin{array}{l}\text { d) Sustaining development in } \\
\text { Indigenous Australia }\end{array}$ & & $\checkmark$ & $\checkmark$ & & $\begin{array}{l}\text { External factors: lack of financial capital; poor coordination; stop-start } \\
\text { funding Internal factors: lack of human capital and means to develop it; } \\
\text { poor local governance }\end{array}$ & {$[73]^{*}$} \\
\hline $\begin{array}{l}\text { e) Engaging Indigenous } \\
\text { Australians (generally) }\end{array}$ & & & $\checkmark$ & $\checkmark$ & $\begin{array}{l}\text { Fragmented governance; inaccurate assumptions; failure to address } \\
\text { power inequities and institutional racism }\end{array}$ & {$[18,71]^{*}$} \\
\hline $\begin{array}{l}\text { f) Engaging Indigenous } \\
\text { Australians (about suicide) }\end{array}$ & & & $\checkmark$ & $\checkmark$ & $\begin{array}{l}\text { Time required to build trust and access communities; considering cultural } \\
\text { appropriateness, e.g., literacy; recruiting, retaining staff; data } \\
\text { collection challenges }\end{array}$ & {$[74]^{*},+$} \\
\hline $\begin{array}{l}\text { g) Governance in remote } \\
\text { Indigenous Australia }\end{array}$ & & $\checkmark$ & $\checkmark$ & & $\begin{array}{l}\text { Low value of engaging in "development"; governance training focuses on } \\
\text { administrative requirements }\end{array}$ & {$[75]^{\wedge}$} \\
\hline $\begin{array}{l}\text { h) Sustainable futures in } \\
\text { Indigenous Australia }\end{array}$ & & $\checkmark$ & $\checkmark$ & & $\begin{array}{l}\text { Disagreement between actors; trust eroded; institutionalization, } \\
\text { inflexibility; poor listening to Indigenous views; governance not focused } \\
\text { on solutions }\end{array}$ & [56] \\
\hline $\begin{array}{l}\text { i) Collaboration in remote } \\
\text { Indigenous Australia }\end{array}$ & & $\checkmark$ & $\checkmark$ & $\checkmark$ & $\begin{array}{l}\text { Top-down, short-term, and not considering maintenance needs; narrow } \\
\text { focus; insufficient understanding of issues; isolated approach; } \\
\text { insufficient testing }\end{array}$ & {$[76]+\hat{i}$} \\
\hline j) Aboriginal perceptions of water & $\checkmark$ & & $\checkmark$ & & Cultural change/westernization erode traditional ties to water & {$[77,78]^{*}$} \\
\hline $\begin{array}{l}\text { k) Aboriginal water values in } \\
\text { water planning }\end{array}$ & $\checkmark$ & & $\checkmark$ & & $\begin{array}{l}\text { Rationalist planning; reductionist worldview—water an asset to be } \\
\text { managed technically; engagement model fails locals }\end{array}$ & {$[2]+$} \\
\hline $\begin{array}{l}\text { 1) Water efficiency in remote } \\
\text { Indigenous Australia }\end{array}$ & $\checkmark$ & $\checkmark$ & $\checkmark$ & & Lack of price on water; higher rates of outdoor water use & {$[39,48]+, \#$} \\
\hline $\begin{array}{l}\text { m) Remote community water } \\
\text { planning processes }\end{array}$ & $\checkmark$ & $\checkmark$ & $\checkmark$ & $\checkmark$ & $\begin{array}{l}\text { External decision-making restricts initiative in aboriginal communities, } \\
\text { influencing willingness to participate }\end{array}$ & [33] + \\
\hline $\begin{array}{l}\text { n) Sustainable water and energy in } \\
\text { remote Indigenous Australia }\end{array}$ & $\checkmark$ & $\checkmark$ & $\checkmark$ & $\checkmark$ & $\begin{array}{l}\text { Limited project timeframes and financial criteria; poor coordination, } \\
\text { cross-cultural awareness, and data management; community's lack of } \\
\text { interest/motivation to participate }\end{array}$ & {$[21]+$} \\
\hline
\end{tabular}

* Literature review; + empirical study; case study; \# desktop modeling; SUWM—sustainable urban water management. 
A wide array of barriers were identified from this broader literature. Institutional and organizational arrangements were highlighted as a key barrier in the majority of studies. This included influence of organizational culture and the rationalist, reductionist approach that works in silos with little coordination between disparate agencies. Limited project timeframes and resourcing, including funds and staff, were raised as issues in a number of studies in both Indigenous and non-Indigenous contexts. As Indigenous protocols and decision-making processes can be more deliberative and take more time than the hierarchical approach, short timeframes are another way in which Indigenous governance processes are limited. Poor communication and engagement, and inclusion of culturally appropriate techniques were also barriers identified in studies in Indigenous contexts, along with a lack of human capital, interest, and capacity in communities.

Although this literature is informative about the challenges faced in different contexts, and although common themes emerge, it remains unclear to what extent the barriers identified are applicable to, or are experienced in, the specific context of water governance for community potable water supplies in remote Indigenous Australia. Context is critical for transferring lessons from collaborative and integrated water initiatives [79], and for management in Indigenous contexts [69], not only to account for historical, governance, and socio-political influences, but also because Indigenous communities are unique with traits and characteristics related to the local setting [80]. Only two peer-reviewed studies ( $m$ and $n$ in Table 1 ) combined all four aspects that constitute the focus of this study, one of which (n) was conducted by the authors as a precursor to this paper. Neither of these studies involved a primary focus on barriers and challenges to collaborative water governance. Therefore, a significant gap in knowledge about barriers to sustainable and collaborative water governance in remote Indigenous Australia exists. Our research presented in the following sections seeks to address this gap in knowledge and provides new insights into how to support a more rapid expansion of sustainable collaborative water governance in Indigenous contexts.

\section{Research Approach}

A qualitative approach was employed to answer the research question drawing on two key sources of data-interviews with practitioners (managers, community project officers, consultants, researchers, policymakers, and so on) working in relation to community water management in remote Indigenous communities, supplemented with a document analysis. The mixed methods approach provided multiple perspectives and triangulation of data, which is important when developing an evidence-based framework for improving practice, as well as to avoid biases that might emerge from reliance on one source of data [81]. The approach rejects purely quantitative assessments of learning and focuses more on narrative [82]; in this sense, we wanted to hear the stories of how and why collaborative water governance and management processes are challenging and to gain insights into the experience of those attempting to manage water in remote Indigenous communities. The research is, therefore, grounded by going back to the people working "at the coalface" in remote community water governance.

\subsection{Scope and Study Area}

The study area (Figure 2) includes remote Indigenous communities in Australia focusing on the northern and central jurisdictions that hold the highest population of Indigenous communities-NT, QLD, WA, and (northern) SA. We applied the following inclusion criteria to guide selection of documents and projects, as well as interviewees: (a) operates in/with remote communities in central and northern Australia; (b) pertains to potable water supply systems, infrastructure, planning, governance, management, and use and excludes broader catchment-scale water planning or projects (such as those that focus on water rights for irrigation, cultural, or environmental flows); (c) pertains to Aboriginal or Torres Strait Island communities that receive regulated water services (effectively excludes very small communities $(<100)$ that are self-reliant for water supply); and (d) has experience with or incorporates elements of engaging local residents in water through collaboration and partnership. 


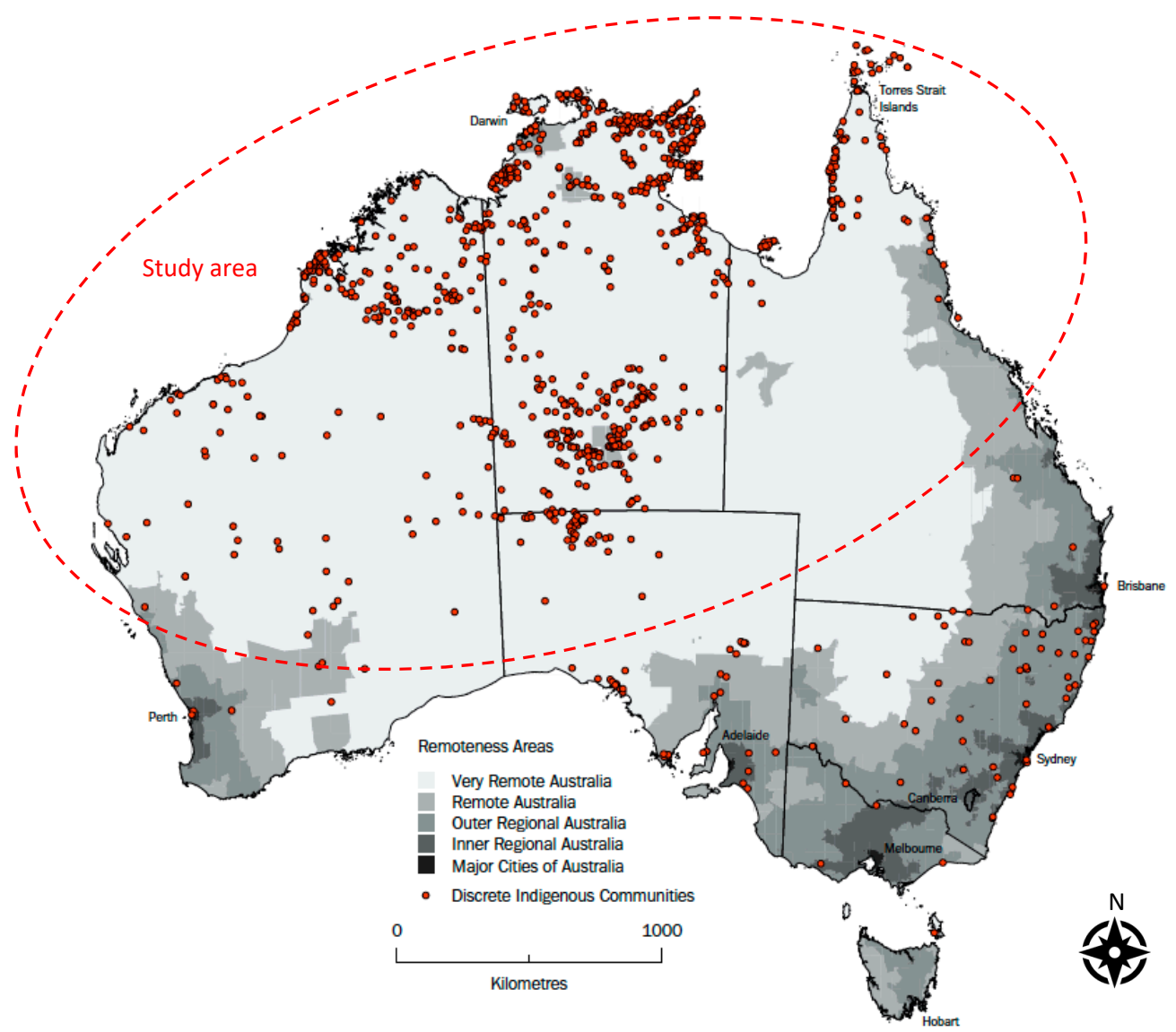

Figure 2. Study area overlaid on map of discrete Indigenous communities (reproduced with permission: [83]).

We broadly defined "barriers" to guide the analysis as any factors (identified by the interviewees or in the literature and documents) that constrain, impede, or prevent the trial, application, implementation, and wider uptake of collaborative, partnership processes for innovation in relation to sustainable community and water outcomes.

\subsection{Data Collection and Processing}

\subsubsection{Document Analysis}

The primary aim of the document analysis was to identify water governance and management activities, and establish the current state of practice with respect to collaborative processes for sustainable community water outcomes in the study area. As introduced in the previous section, very little peer-reviewed literature was available (that met our inclusion criteria) to inform this study, and, as much of the activity and innovation in this space is located within the water sector, we drew on utility and government water program and project reports including evaluations, policy, and planning documents and industry association reports that were available publicly to identify any barriers to collaborative sustainable water governance. The document analysis thus, informed the categorization of the thematic analysis (described in Section 3.3) to a small degree; however, the findings of this analysis also reinforced that there is also very little documentation about challenges and barriers in this specific context.

\subsubsection{Interviews with Practitioners}

Twenty-six interviews were conducted between late 2016 and mid 2018 via phone and in person with professionals working in relation to remote community water. Interviewees were identified 
using a snowball technique [84]. Twelve males and 14 females participated in the interviews working in various states and territories of Australia, including Northern Territory (six), Queensland (12), Western Australia (four), South Australia (one), and multiple jurisdictions (three). Different sectors were represented including water service providers (nine), state/territory government (three), federal government (six), consultants (two), not-for-profit organizations (NFP) (three), and academia (three). We followed a process of informed consent (Griffith University Ethics Reference: GU/ENG/15/14/HREC). We note here that, although community members were not specifically targeted as interviewees at this stage due to the focus on governance and management, five of the interviewees volunteered that they identified as Indigenous and also resided in remote communities, thereby having dual interests and perspectives on the topic. We intended for the analysis to encompass the broader issues in relation to water governance and management from those who were most likely to be familiar with processes, with the intention to then test these perspectives with resident and community views in the next stages of the research (outside the scope of this paper).

A semi-structured approach allowed in-depth knowledge of water management practices and initiatives to be explored and the flexibility to examine the contexts and situations in which practitioners are located, as well as insights into the cultural frames people use in sense-making [85]. An interview guide (Appendix A, Table A1) based around seven key questions with multiple sub-questions was employed to guide the direction of the interviews. Firstly, background was established including roles, responsibilities, and the institutional and governance structures and arrangements within which the interviewee worked. Then, interviewees were asked more targeted questions about experiences with water governance, management, and collaboration initiatives and projects in remote Indigenous contexts, including the drivers for such activities and the ways in which Indigenous communities are involved in water management and governance initiatives. This information helped to put in context the responses to questions about the challenges and obstacles experienced or observed in implementing and achieving sustainability and collaboration outcomes. Interviewees were also asked about success factors, opportunities, and enablers as relevant. In keeping with a semi-structured approach to the interviews, the questions were modified based on responses and, thus, not all interviewees were asked all questions. With limited literature available on this topic, interviewee knowledge of water governance and management practices provided a rich dataset, contextualizing and providing detailed insight into processes, drivers, barriers, and outcomes. Interview data consequently provided the bulk of data for this study and addressed significant gaps in the literature. A number of interviewees also provided non-publicly available documents relevant to the research that supplemented the publicly available documents identified.

\subsection{Data Analysis}

Over 25 hours of interview data were analyzed using thematic analysis. To identify patterns and themes in the contents of data, coding of the transcripts and notes was conducted in NVivo software [84]. For the purpose of identifying barriers, an iterative approach, using both inductive and deductive approaches, was used to refine the themes of relevance and cluster the statements. The first coding cycle [86] generated 37 broad themes related to collaboration in water governance (see Table S1, Supplementary Materials, for a description of themes and coding results). In the second cycle of coding [86], the narrative structure and contextual relationships between themes in the data were considered to identify appropriate categories [87-89]. This categorization was also informed by barriers identified in the broader peer-reviewed literature to sustainable and Indigenous water management (summarized in Table 1), and a secondary, targeted review of analytic frameworks of barriers to identify the different methods and forms for categorization. These barrier analysis studies included related fields such as mainstreaming investments in watershed services [57], distributed energy and energy efficiency [90], decision-making in the energy-food-water nexus [91], adopting carbon farming by farmers [92], mainstreaming biodiversity in governance of economic sectors [93], climate change mitigation in rural land use [94], mainstreaming climate adaptation into development 
assistance [95], and barriers to developing renewable energy supply [96]. The mix of deductive and inductive approaches in analyzing the barriers was appropriate in attempting to generate a new understanding of this topic [89]. Coding was checked at each stage by another research team member, and discussions between researchers were able to resolve any inconsistencies. Final categories were decided based on relevance to the overall aim. The results are presented in Table 2 (see also Appendix B, Table A2 for category descriptions).

\section{Barriers to Sustainable Collaborative Indigenous Community Water Governance}

From the analysis of barriers, 13 barrier themes were distilled, categorized under five key categories: (1) governance arrangements and processes (GA), (2) economic and financial (EF), (3) data and information (DI), (4) capacity/skills, education, and employment (CA), and (5) cultural values and norms (CV) (Table 2).

Table 2. Barrier categories and themes.

\begin{tabular}{|c|c|}
\hline Barrier Category & Themes \\
\hline \multirow{3}{*}{$\begin{array}{l}\text { Governance Arrangements } \\
\text { and Processes (GA) }\end{array}$} & $\begin{array}{l}\text { GA1 Western management structures and processes are rigid, technocratic, } \\
\text { and risk-averse }\end{array}$ \\
\hline & $\begin{array}{l}\text { GA2 Poor coordination and communication within and across institutions } \\
\text { leads to limited institutional learning }\end{array}$ \\
\hline & GA3 Poor housing maintenance \\
\hline \multirow{3}{*}{$\begin{array}{l}\text { Economic and } \\
\text { Financial (EF) }\end{array}$} & EF1 Community dependency on government for local economic activity \\
\hline & $\begin{array}{l}\text { EF2 Short-term funding cycles, under-funding, and preference for capital } \\
\text { investments over ongoing management }\end{array}$ \\
\hline & EF3 Remote water supplies not financially self-sustaining \\
\hline \multirow{3}{*}{$\begin{array}{l}\text { Capacity/Skills, Education, } \\
\text { and Employment (CA) }\end{array}$} & $\begin{array}{l}\text { CA1 Lack of capacity in water service provider organizations for } \\
\text { collaborative approaches }\end{array}$ \\
\hline & CA2 Lack of local skills, awareness, and education in water systems \\
\hline & CA3 Lack of pathways to local employment in water sector \\
\hline \multirow{2}{*}{ Data and Information (DI) } & DI1 Poor data management processes \\
\hline & DI2 Lack of local and disaggregated data on water sources and consumption \\
\hline \multirow{2}{*}{$\begin{array}{l}\text { Cultural Values and } \\
\text { Norms }(\mathrm{CV})\end{array}$} & $\begin{array}{l}\text { CV1 Indigenous cultural and social norms, protocols, and values are diverse } \\
\text { within and across communities }\end{array}$ \\
\hline & $\begin{array}{l}\text { CV2 Low service provider understanding of Indigenous cultural protocols, } \\
\text { values, and norms }\end{array}$ \\
\hline
\end{tabular}

The barriers outlined in Table 2 occur at multiple levels and affect and are affected by different aspects of the water management system and actors within it. Further analysis is provided in Appendix C, Table A3, in which the barriers are presented and described in detail according to how they operate and interact at each of the three levels of regional, local, and individual. Following is a detailed discussion of the results of the barriers analysis, including exemplar statements taken from interviews that illustrate the range of issues identified and how these were experienced by practitioners across their varied situations and jurisdictions.

\subsection{Governance Arrangements and Processes (GA)}

Interviews reinforced that systems of governance, when not centered around communities and their long-term needs, can perpetuate problems and often create new ones through imposing narrow thinking and short-term solutions. This theme was also raised as a significant barrier from a project trial evaluation analyzed as part of the document review [97]. Because specific projects are predominantly 
determined from within water agencies and organizational processes, a technical or "service delivery" focus that aligns with agency priorities ensues (GA1), as stated by a regional planning manager.

"I see most stuff happening in a place like [this] is done through the government to go out and have a service delivery mindset, and they often do things in isolation... I just think it's the wrong approach for these communities." (Regional Manager)

The short-termism that is prevalent in water governance decision-making has implications that cascade through to funding priorities, design of projects, and the relationships between water agencies and communities via engagement methods used. In one tropical region, for example, an interviewee identified how ongoing water restrictions put in place to manage water demand led to increased health risks and potential outbreaks of water-borne diseases because residents need to store water for use while water is turned off, but do so in unsanitary ways that are available to them, unaware of safe storage practices. Problem definitions and solutions considered are, therefore, constrained by the institutional arrangements and priorities.

"So, governments are not very good at taking risks or being innovative either... so it's really hard to push an exploratory innovative agenda within a government organization ... even though they say that's what we need." (Federal Manager)

This lack of innovation is also exacerbated by poor coordination and communication across agencies-another key and ongoing barrier (GA2). Implicit in many statements were concerns about the quality of communication. One interviewee highlighted this theme of the need to capitalize on previous efforts to improve water coordination through dialogue.

"Lack of dialogue is a major barrier to collaboration. Now, we have all the ingredients to do things right, but what we ain't doing is talking to one another to how to firm up this space." (Project Officer)

This lack of coordination and communication was a constraint in some areas, reinforcing a well-recognized issue in Indigenous Australia, whereby government agencies and policies are very slow to learn from mistakes, as the statement below describes succinctly.

“Despite all the project learnings, those learnings haven't been implemented in the next project, even though they know. It happens again and again. Indigenous communities keep telling us what works but again and again 'you're not listening'." (Researcher)

Poor coordination is linked to lack of ownership for those issues that "fall through the cracks" in the system. Issues of maintenance of public housing infrastructure and equipment in remote Indigenous communities (GA3) were raised as emblematic of this issue. The vast majority of housing in remote Indigenous communities is public housing (owned by the State) usually with long-term leases given to tenant families. Thus, responsibility for various aspects of maintenance and care of homes, for example, rainwater tanks, is split between housing departments at the state or territory level and tenants. This also creates split incentives for investment in improved housing and water-related infrastructure where those that bear the costs of those investments are not necessarily receiving the benefits. This led to a situation where housing maintenance is underfunded, which leads to poor state of assets and perpetuates negative perceptions of Aboriginal and Torres Strait Islander communities, as illustrated in the following point:

"... housing's budget is \$1200/person/year, not much when you consider the cost of getting a [tradesman] out to fix something. It leads to a misconception that Aboriginal people trash their houses." (NFP Manager) 
Poor coordination and governance of maintenance of household water infrastructure led to situations where it is not uncommon for fixing of leaks to take weeks, months, and sometimes years. Furthermore, with little education provided to community members of contamination risks and safe storage and use, interviewees identified this as a key barrier on multiple fronts. It can undermine efforts to implement water quality or conservation activities and erode agency of community members, leading to, as one manager described "a vicious cycle of 'well, why do I bother?'".

\subsection{Economic and Financial (EF)}

Economic and financial factors were also critical challenges for implementing more collaborative, sustainable processes. As is well documented in literature on remote Indigenous livelihoods and economic development, local economic activity in communities is derived primarily from government services, grants, welfare payments, and investments $[47,98]$. This was seen by water practitioners to perpetuate dependency and limit agency of community members to engage effectively in water management activities (EF1). The resultant power imbalance means that the conditions for genuine collaboration are unavailable in most remote Indigenous communities, because government employees hold knowledge and power unavailable to locals. At the infrastructure level, the tendency for management to invest in capital infrastructure over long-term operation and maintenance (O\&M) considerations led to a situation where $O \& M$ is underfunded. This has significant implications for sustainable water systems, as the following manager observed:

"If we're going to put infrastructure in, we really need to think about what capacity is there to operate and maintain it? ... otherwise we'll just end up ... where it's just not run properly, and it breaks down." (Regional Manager)

This short-term planning and financing approach is also evidenced by the view of social considerations and community involvement and collaboration as a "nice to have" rather than an essential process to ensure decisions are relevant to the local context (EF2). This translates to poor allocation of funding to these aspects of water, as one utility manager identified.

"[The program] has always been underfunded. Innovation is something that hasn't really happened as a result ... we need to skill people up for long-term relationship building but there's no budget for that." (Utility Manager)

At the consumer side of water economics, a lack of price on water consumption was identified as a significant barrier to sustainable management. With no effective revenue base generated to offset costs of operation, a continued financial investment from outside is needed to keep water services operating (EF3). The current government-led discourse around financially self-sustaining communities was, therefore, challenged by practitioners who reflected on the reality of the situation.

"I think you're really setting the bar a bit too high to think you can actually achieve a financially sustainable water supply up here." (Regional Manager)

At the household level, the lack of payment for water was linked to high per capita demand in remote communities, thereby challenging household engagement in water conservation activities when benefits could not be connected to financial gain (a common message of benefits of energy efficiency activities, for example).

\subsection{Data and Information (DI)}

Poor data management processes and limited analysis skills (DI1) were identified as a key theme under the data and information category. Many organizations had limited capacity for managing data to fulfil sustainability goals, as the following statement attests: 
"At the moment, we wouldn't know what is due ... if it was done, how it was done, who did it, how long it took, and how much it cost ... we don't capture anything and that's a really bad area of the organization is data capture." (Council Manager)

A lack of disaggregated local water data to inform decisions about pathways to sustainable water supply and demand within communities (DI2) was also a common theme. Existing water data collection processes were described as typically reliant on manual and ad hoc collection and recording of data, in turn linked to lack of resources, staff, and a priority on quality data within service provider agencies. Very little is known about water source sustainability including size and quality of aquifers, as well as quantity and habits of use, except where investments in automated data collection, i.e., smart water meters (which, at the time of interviews, were only available in a handful of communities).

"... we need to find out where the water is going but the big issue is we don't have good data on consumption in most communities." (Utility Officer)

Furthermore, although regular water quality testing is mandatory, a suite of associated challenges including handling of samples and delays in processing due to distance to laboratories also hinder real-time status updates, and they often lead to lag times in response to any quality issues. The poor data significantly limit understanding of the range of options available to sustainably manage water in communities.

\subsection{Capacity/Skills, Education, and Employment (CA)}

Closely linked to issues with appropriate information being available was identification of limited community engagement skills and capacity within water agencies to engage with a broader view of socio-ecological and socio-economic aspects of water (CA1). One utility engagement officer highlighted their lack of experience in running community projects and needing to partner with others with skills in the field of community engagement. However, leadership capacity was also identified as an issue.

"... councilors wouldn't have any idea of what I do and that they're down to provide safe, reliable drinking water, which is slightly alarming." (Council Manager)

Furthermore, interviewees suggested that the water sector's role in contributing to development of remote Indigenous communities was not backed by organizational or regulatory priorities which focus on cost-effective infrastructure provision, which is measured primarily on capital investments rather than long-term broader indicators of wellbeing and development.

With regard to community capacities, limited local skillsets in relation to sustainable management and use of water were identified as a strong sub-theme (CA2), as summed up in the following statement:

"There's definitely local capacity challenges ... that's just a really big part of their challenge is the human capacity side of things." (Federal Manager)

Furthermore, interviewees pointed to limited local training programs and employment opportunities in communities in the water sector as constraining capacity building and local development (CA3).

This was related to low skillsets within communities and reliance on externally appointed staff, with a high turnover rate in remote areas, which also leads to loss of knowledge and skills in communities. Where accessible training does exist, poor quality and delivery was also identified as a barrier to sustainable and collaborative water governance.

"We're finding that a lot of the providers have come in, ticked the box, and walked away... So, while we've got a lot of trained staff... we're finding that they've done days and days of (for example) how to take a water sample, but they don't know how to take a water sample." (Water Manager) 
The broader situation for those living in remote communities is that opportunities and access to markets is much more limited than urban or regional centers.

"It's a bit like punching yourself in the face every day, going out, and saying we want to see these communities stand on their feet ... but there's no-one who employs them ... they've got this idea that we'll just train them up and the market will take care of everything else, but that's just bullshit." (Federal Manager)

There is a significant opportunity for key services such as water to help bridge these market gaps and build community capacity.

\subsection{Cultural Values and Norms (CV)}

A key theme was related to the different cultural values, norms, protocols, and perspectives between Indigenous and traditional management associated with mainstream Australian culture. Limited awareness and consideration of cultural differences between Western and Indigenous governance and ways of knowing appears to be a root cause of many other barriers identified.

"The whole Western system that's being wrought on these communities ... it's generally quite in opposition to who they are as a people... [it] has really been a bit of a train wreck I think in terms of destroying people's motivation or sense of responsibility." (Federal Manager)

A theme reflected on the cultural differences and perceptions in relation to the relatively recent emergence of "whitefella" water infrastructure and the lack of cultural norms and leadership in concepts such as turning off taps and the need to conserve water, for example. This cultural difference between Indigenous and Western water management approaches that are hierarchical was viewed as a contributor to low interest or willingness to participate in conservation or sustainability programs by community members. Low motivation to participate was exacerbated by a perceived lack of recognition and skills to apply culturally sensitive community engagement methods (CV2).

"The [project manager] was quite insensitive about how to come into people's homes, interrogating them about their behaviors... [they] pushed [their] way in and made comments about the state of the house ... That's what they considered community engagement." (NFP Manager)

Such approaches not only diminish effectiveness of investments in community engagement, but also reinforce negative outcomes including disenfranchisement of residents, rather than providing a means to build relationships and bridge gaps in understanding between government and community. One water manager highlighted the criticality of culturally sensitive, inclusive, and collaborative decision-making in the context of deeper issues of lack of trust carried over from many decades of racial discrimination in government activities.

"So, there's this underlying viewpoint that all these whitefellas are making decisions and they're actually wrecking our lives." (Water Manager)

This was linked to the issues with lack of local employment and voices from within the community as messengers about sustainable water.

"The failing of our project is we didn't really have a community focal point, a champion in the community." (Consultant/Manager)

Although there is acknowledgement that efforts are being made to conduct water management in more culturally sensitive ways, using tools and engagement methods tried and tested in urban and regional centers is not going to be relevant in many remote communities. Interviewees also recognized challenges for which the sector may not be currently equipped to deal with, including navigating the sheer diversity of Indigenous Australia including language and cultural differences (CV1). One water officer explained the challenge with a particular community they worked with. 
"The issue here is (in community) there's five different tribes and language groups ... So, there's a language barrier... Generally, the older people ... might have trouble with English or don't want to talk to a whitefella." (Utility Engagement Officer)

\section{Discussion}

The growing sustainable water crisis in remote Indigenous Australia brings into question the underlying structures and processes of water governance. By conducting a contextualized analysis from the perspective of water managers and practitioners in remote Aboriginal and Torres Strait Island communities, new data on, and insights into the nuanced and challenging environment in which remote community water actors and activities operate were generated. The identification of five main groups of barriers and thirteen sub-areas that challenge sustainable and collaborative water governance shed light on why the potable water management regime continues to employ management approaches that are not fit for this context and how more transformative approaches might be initiated and sustained.

The research highlights the increasingly apparent need to address foundational governance issues and overcome the disproportionate effects of poor management in remote Indigenous communities. Governance arrangements, institutions, and structures were identified as a key barrier, an issue that was raised in the broader sustainable water management literature [7,22,72]. However, a key differentiation in remote Indigenous contexts is the disproportionate impact of the traditional Western water management paradigm on Indigenous Australians who have been considerably marginalized in decision-making in Australia. Continued imposition of significantly different cultural perspectives on water and governance contributed directly to negative impacts in Aboriginal and Torres Strait Island residents' health, wellbeing, willingness to participate, and overall community resilience. These lessons echo those from Indigenous engagement and program participation lessons in other sectors $[71,76,99,100]$. The research illuminated in detail a number of problematic features associated with this technocratic management paradigm, including hierarchical decision-making that reflects the perspective of the dominant actors (i.e., government and service provider management), compartmentalization of water issues which are intricately connected, and poor communication and coordination across actors. Insufficient and poorly directed funding, resourcing, and training for staff and communities to innovate beyond core business activities were also reinforced as significant contributing factors. Together, this environment hinders social learning across the sector which is needed to avoid repetition of poor and ineffectual practices and repair the broken relationship between government and Aboriginal and Torres Strait Islanders.

Impacts of this approach also extend to broader societal impacts, as higher costs to government service providers (funded by taxpayers) arise in the long term from infrastructure lifespans that are often much shorter $[33,47,101]$, water is supplied and used inefficiently, and an external pumping in of resources to community water systems is perpetuated. Although technical and infrastructure solutions will continue to be foundational to ensure clean, reliable water services in remote communities, a key conclusion from this research is that continued investment in short-term technical fixes without a more holistic, collaborative, and strategic approach will perpetuate the problems that have been ongoing for decades. All water governance activities must now strive to contribute beyond the confines of a "service delivery" approach and focus planning and management efforts on achieving broader transformative community goals within a vision of self-determining and empowered communities.

This research also revealed barriers specific to this context that were not identified in the broader literature and yet will be critical to address in progressing a transformative community water agenda. These include: poor public housing maintenance, which is an issue of magnitude in relation to water sustainability in remote Australia, more so than for urban environments; a poor understanding of fundamental aspects of water in communities including supply sustainability and consumption data; low education levels with respect to clean and safe water supply and use in communities; a lack of intercultural and cross-cultural awareness and skills in management; poor technical skills 
in communities; and very limited pathways for locals to engage in and build long-term capacity to address water issues.

In considering how the challenges to sustainable water collaborations might be overcome within the diverse social, geographical, and institutional context of remote Australia, a number of key insights into actions, strategies, and mechanisms, e.g., opportunities and enablers, also emerged from the analysis (Table 3). Firstly, although the role of government structures and institutions in perpetuating problems of dependence and unsustainability in remote Indigenous communities is well documented $[7,15,36,46,68,73,102-104]$, governments clearly have a critical role in transforming Indigenous water governance locally and regionally because they have the authorization and resources that other actors do not. Government and associated water sector agencies, along with other key community services, could play a pivotal role through strategic investments-funding and resourcing - to initiate a positive spiral of community change [64]. Acknowledging this important role of government, a further important conclusion for both research and policy, however, is that no single actor or strategy can facilitate the transformation of remote Indigenous communities that is needed on its own. There is no "silver bullet" in such complex sustainability issues; there is just a need for more flexible and adaptable governance mechanisms that incorporate all actors at different levels and scales.

Table 3. Opportunities and enablers for tackling barriers to collaborative sustainable water governance.

\begin{tabular}{ll}
\hline \multicolumn{1}{c}{ Barriers Identified } & \multicolumn{1}{c}{ Opportunities and Enablers } \\
\hline $\begin{array}{l}\text { Governance Arrangements } \\
\text { and Process }\end{array}$ & Cross-agency coordination; dialogue-based collaboration \\
\hline Economic and Financial & Broadened funding criteria and timeframes \\
\hline $\begin{array}{l}\text { Capacity/Skills, Education, } \\
\text { and Employment }\end{array}$ & $\begin{array}{l}\text { Employee cultural awareness training; local training; community water } \\
\text { champions; flexible employment models; water education program for } \\
\text { communities; community leadership and capacity development; small-scale } \\
\text { "safe-to-fail" learning experiments }\end{array}$ \\
\hline Data and Information & $\begin{array}{l}\text { Local systemic baseline; smart metering; knowledge sharing and feedback to } \\
\text { communities on water status; monitoring and evaluation of projects }\end{array}$ \\
\hline Cultural Values and Norms & $\begin{array}{l}\text { Culturally informed engagement, including local language translations, } \\
\text { deliberation, and prioritization over longer timeframes; partnership approach } \\
\text { to governance; cultural awareness training for managers }\end{array}$ \\
\hline
\end{tabular}

Secondly, to overcome the significant gap in knowledge about water at the community level, conducting local water baseline assessments will be necessary to establish a foundation for evidence-based decision-making and monitoring, and measuring of progress and evaluation of factors that influence sustainability outcomes. Smart meters were identified as a desired technology solution; however, interviewees reinforced the need to combine social and qualitative data for a comprehensive understanding of the human-water interactions. Knowledge sharing and improved communication between actors are also parts of a collaborative approach that was raised as an opportunity to facilitate transformative change. Sharing lessons about what works and what does not in remote community water management through real-world tangible examples and case studies was identified as a means to generate interest and enthusiasm. Interviewees referred to examples from New Zealand, Canada and other areas and suggested that communities are interested in how other people in different contexts solve similar problems.

Thirdly, to address capacity issues, water education programs in communities and linking management outcomes to local employment and economic development opportunities were viewed as critical factors in encouraging participation and involvement in water management. This issue is well identified in the literature and is becoming increasingly common in practice. However, this research identified that these too need to be tailored to the local environment and culture. For example, creating local employment within the water sector was seen as an opportunity; however, in remote communities, 
flexible work arrangements were viewed as a culturally appropriate option to encourage participation, one which is not often the norm in government organisations. Investing in local employees for water roles can also counteract to some degree the very high rates of turnover of external staff, which is challenging for the relationship building and continual learning that are essential for collaborations. A number of interviewees raised the concept of community "champions" - trusted local individuals that act as a liaison between water agencies and communities-as key to breaking down some of the structural and communication barriers. Some interviewees suggested formal roles would be most appropriate, for example, modeling the Land and Sea Ranger program that employs thousands of Aboriginal and Torres Strait Islander peoples in their local regions [105]. Others identified more informal processes that work on an as needs basis, and that connect with existing local networks such as health and development groups and school education programs.

A fourth area of opportunity concerns the intercultural and cross-cultural awareness and skills that are considered critical to collaboration in this context. Generic strategies and assumptions directly transferred from urban contexts were shown repeatedly to be inappropriate when engaging Indigenous communities $[17,18,23,103,106]$, and different meanings and interpretations associated with aspects of water management, such as technologies, and key messaging of programs, need to be considered in design. Delivering water education and management materials in local languages were included as ways that service providers are being more culturally sensitive and inclusive. However, there are over 125 Indigenous Australian languages still in use, and many of these have small and diminishing numbers of native speakers [107]. Thus, it is unlikely that all Indigenous Australians can be engaged in their first language, and this has equity implications that need to be considered. An intercultural approach $[2,7,75,108]$ goes beyond training and translation of materials to "creating spaces enabling cultures to truly meet". Dialogue and relationship-building activities are foundational here to encourage multi-way learning and dialogue about cultural practices, meanings, and perceptions to overcome the cultural constraints that prevent full collaboration between actors.

\section{Conclusions and Recommendations}

In this paper, we aimed to answer the following question: What factors prevent uptake and implementation of sustainable collaborative potable water governance processes for transformative outcomes in remote Indigenous communities? We have presented new theoretical and empirical insights into the key factors that prevent transformative and collaborative water governance in remote and Indigenous Australian communities. By examining the practice of water governance and management from the perspectives of those working on the ground in remote communities, a deeper and contextualized understanding of the nuances and unique aspects of remote community water governance was established. This study showed that, to facilitate a more supportive environment for sustainable, collaborative water governance to be taken up at scale, a complex array of challenges, covering governance and institutional arrangements, data and information barriers, constraints with capacity and skills of different actors, economic and financial factors, and the differences in cultural values, norms, and protocols, must be addressed through a comprehensive and coordinated approach. This is an important contribution to knowledge in this field; however, it provides only a snapshot in time, and findings should be considered in that context.

When considering transformative outcomes, the diversity of and different scales that these barriers and opportunities exist at, as well as the interactions between them, reinforce that no one solution or actor can be relied upon to solve these complex issues, and that engagement across all actors and activities will be needed. Many international contexts, including those in post-colonial settler countries such as Canada, New Zealand, and the United States, as well as remote and rural communities in developing country contexts that are also vulnerable, marginalized, and dealing with significant water quality and security issues, are likely to have similar opportunities in relation to addressing governance, capacity, economics, and cultural aspects of water systems. The findings from this study are, therefore, broadly generalizable to other communities and settings. However, due to the high level 
of localization that pervades remote Australia, critical interpretation of the findings will be necessary for contexts where differing governance arrangements and government-community relations are present. Consideration of the presence of these barriers in the local context and the potential for certain actions or strategies to enable change should, therefore, be preceded with a detailed analysis of the local context that considers geographic, political, social, and cultural factors, as a means to guide the practice of water governance.

We encourage further research, building off this study, into the practice of sustainable water governance in cross-cultural contexts, and we envision the outputs to inform and be used in conjunction with policy and design of water governance activities. Research recommendations arising from this research are as follows:

- Transformative water governance is an emerging area of research, and further localized studies in Australia and internationally are needed to establish whether the barriers identified here, and the suggested opportunities and enablers are in play in other local water contexts and how actors and activities influence them;

- In keeping with an empowerment and self-determination ethic, community perspectives on sustainable collaborative water governance will be a critical area for research to fill existing knowledge gaps as part of a decolonizing research agenda [109] and to inform transformative outcomes in practice;

- Short-term snapshots, as this research provides, are useful to prompt action, but longitudinal studies as part of strategic long-term commitments to change across all actors will be required to create and monitor impact on the ground;

- Further long-term partnerships are required among researchers, government agencies, and Indigenous organizations that can shape an evidence-based agenda for empowering water governance in Indigenous communities.

The following policy and management recommendations also emerged through this research:

- In addressing barriers, lessons from the past must be heeded to not perpetuate short-term, politically driven, and generic "solutions"; rather, adaptable, flexible, and robust systems of governance that are responsive to local conditions and facilitate change at greater scales and depth should be the focus;

- In order to achieve the vision of sustainable development that "leaves no one behind" [110], governments and government-supported agencies, with primary responsibility for water management, must foster a genuine commitment and organizational culture of collective and collaborative learning and decision-making;

- Self-reflection and openness to challenging existing institutional structures such as rigid regulatory regimes, funding criteria, and delineations between departmental responsibilities will be a necessary part of long-term organizational and cultural change;

- Small-scale experiments should be a focus of action to build a robust foundation of contextualized knowledge with consideration of how success factors can be scaled up across regions;

- Investments in quality data collection and capture systems including smart meters and longitudinal community surveys, as well as capturing data through Indigenous aligned methods such as yarning (storytelling and conversation), are also essential to building capacity of the sector;

- Facilitating transformative governance requires commitment of resources at national, regional, and local levels, including strategic funding and personnel.

There is great urgency to address Western society's failures in supporting Indigenous people in their aspirations and livelihoods. There is a need to adopt a more transformative, long-term view of Indigenous community water systems within the water sector, which is inclusive of socio-cultural, governance, environmental, information, and capacity factors, and where issues and options are assessed as part of a strategic process. Such a process moves beyond incremental and systemic 
responses to coordinate fit-for-purpose and fit-for-place water solutions while supporting collective action at greater scales and depth of change [41]. At its core, this is a reorienting of a system geared toward institutional priorities that must place Indigenous peoples' perspectives, needs, health, and wellbeing at the heart of water governance in Indigenous communities.

Supplementary Materials: The following are available online at http://www.mdpi.com/2073-4441/11/11/2410/s1: Table S1: Themes generated from first cycle coding of practitioner interviews in remote Indigenous community water management, Australia.

Author Contributions: Conceptualization, M.J.; methodology, M.J.; validation, M.J., C.D.B. and R.A.S.; formal analysis, M.J.; investigation, M.J.; writing—original draft preparation, M.J.; writing—review and editing, M.J., C.D.B., and R.A.S.; visualization, M.J.; supervision, C.D.B. and R.A.S.; project administration, M.J. and C.D.B.; funding acquisition, C.D.B.

Funding: This research was supported through an Australian Research Council (ARC) Linkage Project Grant (Number: LP140100118) and a doctoral research scholarship supported by Industry funding from Ergon Energy Corporation and NT Power and Water Corporation.

Acknowledgments: The authors would like to acknowledge the practitioners that generously shared their time and knowledge to be interviewed for this research. We also acknowledge our partners in the Remote and Isolated Essential Services Project of which this doctoral research is a part-Queensland Department of Natural Resources, Mines, and Energy, Torres Strait Island Regional Council, Torres Strait Regional Authority, University of Queensland, Ergon Energy, Power, and Water Corporation, and WA Water Corp. We also acknowledge the Aboriginal and Torres Strait Island peoples of Australia who never ceded sovereignty, their Elders past, present, and future, and we extend that to Indigenous peoples globally who have been stewards of water and caretakers of the land for time immemorial. We envision this invaluable knowledge will be recognized more and more in the future for the unique insights offered into living in harmony with our natural world.

Conflicts of Interest: The authors declare no conflicts of interest. The funders had no role in the design of the study; in the collection, analyses, or interpretation of data; in the writing of the manuscript, or in the decision to publish the results.

\section{Appendix A}

The interview guide was used to establish as much information about governance, management, and projects implemented in remote Aboriginal and Torres Strait Island communities. Interviews were semi-structured and, hence, the guide was used loosely, i.e., not all interviewees were asked every question. Rather, questions were asked as appropriate depending on previous answers. 
Table A1. Interview guide.

\begin{tabular}{|c|c|c|}
\hline & Questions & Notes for Interviewer \\
\hline 0 & Preliminary/introductions & Establish name, position, experience working in remote aboriginal and Torres Strait island communities/water sector. \\
\hline 1 & $\begin{array}{l}\text { What projects are you aware of that involved } \\
\text { management of water in Aboriginal or Torres Strait } \\
\text { Island communities in the past } 15 \text { years? }\end{array}$ & For each project/program, fill in as much detail as possible. \\
\hline \multirow[t]{2}{*}{ 1a } & Where was this project located & Which communities? State/territory? \\
\hline & & Why were these locations chosen? \\
\hline \multirow[t]{3}{*}{$1 \mathrm{~b}$} & Who were the proponents of the project & \\
\hline & & Who ran them? \\
\hline & & Where did funding come from? \\
\hline \multirow[t]{2}{*}{ 1c } & Were you involved directly? and at what stage/s? & \\
\hline & & $\begin{array}{l}\text { If no, ask as much detail about the project location, who was involved, get any contact details/reports and thank them } \\
\text { for their time. }\end{array}$ \\
\hline \multirow[t]{2}{*}{$1 \mathrm{~d}$} & What were/are the project aims and objectives? & \\
\hline & & Water, water and energy (or other combination of aims)? \\
\hline 1e & $\begin{array}{l}\text { Were there short-, medium-, or long-term components } \\
\text { of the project/program? }\end{array}$ & Was a program logic used? Was the project part of a larger initiative? (i.e., if the funding stops but does the project stop? \\
\hline \multirow[t]{2}{*}{2} & What were the motivations for the proponent to initiate & he project? \\
\hline & & $\begin{array}{l}\text { If not clear from the objectives-these can be quite different-e.g., may have been government mandate or internally } \\
\text { driven, example of best practice, etc. }\end{array}$ \\
\hline \multirow[t]{4}{*}{3} & $\begin{array}{l}\text { How much information was there about this } \\
\text { community/ies before initiating the project? }\end{array}$ & \\
\hline & & What data and evidence was this project based on, how was a need determined? \\
\hline & & Where was data sourced from? \\
\hline & & Was it qualitative or quantitative? \\
\hline \multirow[t]{3}{*}{4} & Was there a community engagement/collaboration com & onent of this program? \\
\hline & & If yes continue with these questions. \\
\hline & & If no, ask why not? What was the method for achieving the objectives? \\
\hline
\end{tabular}


Table A1. Cont.

\begin{tabular}{|c|c|c|}
\hline & Questions & Notes for Interviewer \\
\hline $4 \mathrm{a}$ & $\begin{array}{l}\text { How significant a driver was community involvement } \\
\text { for the program/project? }\end{array}$ & $\begin{array}{l}\text { (Link back to objectives) Who were the participants? Were there particular cohorts targeted? Why? Age, economic } \\
\text { status, other? }\end{array}$ \\
\hline \multirow[t]{3}{*}{$4 \mathrm{~b}$} & $\begin{array}{l}\text { What role did community play in governance of the } \\
\text { project? What method/s were used to engage the } \\
\text { community? How were they engaged? }\end{array}$ & Establish extent of power sharing-full collaboration from beginning to end, driving it, consulted, etc. \\
\hline & & At what stages of the project/program were the community involved? \\
\hline & & Was the design based on literature or evidence-based? \\
\hline \multirow[t]{3}{*}{5} & What were the challenges and obstacles to achieving the $\mathrm{c}$ & aims or objectives? \\
\hline & & What was challenging to achieving sustainability outcomes? \\
\hline & & What was challenging to collaboration with communities? \\
\hline \multirow[t]{2}{*}{6} & Were the project objectives achieved? & \\
\hline & & For example, water reduction, management, education, capacity building. \\
\hline \multirow[t]{2}{*}{$6 \mathrm{a}$} & What were the factors that contributed to any successes o & r achievement of objectives? \\
\hline & & Was it deemed a success and what contributed to that? \\
\hline \multirow{4}{*}{$6 \mathrm{~b}$} & & What were the terms of reference for the evaluation? \\
\hline & & Was it independent? If not, who conducted it and what methods did they use? \\
\hline & & Can I get a copy of this document or access to key findings? \\
\hline & & Was there any feedback from community about the methods and outcomes included? \\
\hline \multirow[t]{4}{*}{$6 c$} & Were any further recommendations made? & What were these? Who were they made by? \\
\hline & & Have they been taken up? \\
\hline & & If yes, describe what stage are they at. \\
\hline & & If no, why not? What is preventing them being implemented/taken up? \\
\hline \multirow[t]{4}{*}{7} & How can I find out more information about this project? & \\
\hline & & Any written materials, colleagues I can contact within your organization who could help? \\
\hline & & Any evaluations or findings documents? \\
\hline & & Are there any restrictions on usage for publications, permissions needed? \\
\hline
\end{tabular}




\section{Appendix B}

Table A2. Barrier and enabler category descriptions.

\begin{tabular}{|c|c|}
\hline Barriers and Enablers Category & Description \\
\hline $\begin{array}{l}\text { Governance processes and } \\
\text { arrangements }\end{array}$ & $\begin{array}{l}\text { Structures, communications, coordination, and organizational factors } \\
\text { across water, housing, and related infrastructure for a community and } \\
\text { the interactions with broader networks and functions of state; also } \\
\text { across the design, planning, implementation, monitoring and evaluation } \\
\text { phases of water sustainability projects and programs that seek to } \\
\text { involve communities }\end{array}$ \\
\hline Economic and financial & $\begin{array}{l}\text { Relates to economy, economics of projects and funding, } \\
\text { cost-effectiveness, financing and investment, economic development in } \\
\text { communities, and pricing/charging of water and water services }\end{array}$ \\
\hline Data and information & $\begin{array}{l}\text { Relates to the collection, collation, and analysis of both quantitative and } \\
\text { qualitative data relevant to manage water sustainably in a community, } \\
\text { i.e., metering and monitoring, information communication and } \\
\text { technology (ICT), analysis of capabilities of/for communities relating to } \\
\text { water and community demographic and baseline information }\end{array}$ \\
\hline $\begin{array}{l}\text { Capacity/skills, education, and } \\
\text { employment }\end{array}$ & $\begin{array}{l}\text { Of agencies and services provider staff and organizations, as well as } \\
\text { community members, relating to sustainable water management } \\
\text { principles including conservation, efficiency, equity, and quality } \\
\text { Systemic thinking and tools to consider issues holistically and consider } \\
\text { and plan for long-term outcomes; also in relation to education, } \\
\text { employment opportunities, and capacity building for long-term } \\
\text { sustainable change }\end{array}$ \\
\hline $\begin{array}{l}\text { Cultural values, norms, and } \\
\text { practices and working } \\
\text { cross-culturally }\end{array}$ & $\begin{array}{l}\text { Incorporates concepts of cultural values, norms, and practices, language } \\
\text { use and interpretation and meaning associated with various } \\
\text { communications and infrastructure, technology, strategies and } \\
\text { relationships, and the interaction between differing cultures (primarily } \\
\text { Indigenous and Western), and how those differences are managed } \\
\text { within this context }\end{array}$ \\
\hline
\end{tabular}




\section{Appendix C}

Table A3. Barriers experienced at regional, local, and individual scales.

\begin{tabular}{|c|c|c|c|}
\hline Barrier & Regional, Cross-Community, and Institutional & Local Community Projects/Program & Individual Individual/Household or Groups \\
\hline \multicolumn{4}{|c|}{ Governance Arrangements and Process (GA) } \\
\hline $\begin{array}{l}\text { GA1 Western management } \\
\text { structures and processes are rigid, } \\
\text { technocratic, and risk-averse }\end{array}$ & 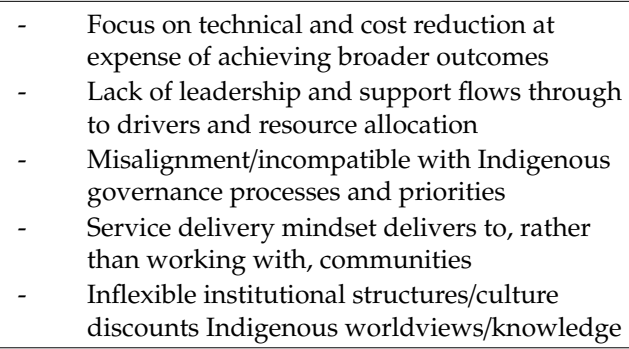 & $\begin{array}{l}\text { Problem definition is narrow, excluding a range of } \\
\text { possible options/solutions } \\
\text { Agency prioritization processes inequitably } \\
\text { invest/distribute resources across regions } \\
\text { - Top-down decision-making limits partnership and } \\
\text { collaboration and fails to address deeper needs } \\
\text { Projects lack holistic qualitative, } \\
\text { community-based methods }\end{array}$ & $\begin{array}{l}\text { - } \quad \begin{array}{l}\text { Perpetuates dependency on government, } \\
\text { reinforces lack of agency in communities }\end{array} \\
\text { - } \quad \begin{array}{l}\text { Encourages disconnect from water system } \\
\text { and decisions making process }\end{array} \\
\text { - } \quad \begin{array}{l}\text { Devalues local lived experience, anecdotal } \\
\text { evidence, and other ways of knowing }\end{array}\end{array}$ \\
\hline $\begin{array}{l}\text { GA2 Poor coordination and } \\
\text { communication within and across } \\
\text { institutions leads to limited } \\
\text { institutional learning }\end{array}$ & $\begin{array}{l}\text { - Unclear roles, responsibilities, and lack of } \\
\text { systemic view of water in communities } \\
\text { - Results in poor design, inefficiency, and } \\
\text { increased costs, issues critical to long-term } \\
\text { sustainability “fall through the cracks" } \\
\text { - Reinforces reactive management and prevents } \\
\text { institutional learning }\end{array}$ & $\begin{array}{l}\text { - "Problems" considered in isolation rather than } \\
\text { systemically and integrated } \\
\text { - Results in repetition/failure to capitalize on efforts } \\
\text { and investments already made }\end{array}$ & $\begin{array}{l}\text { Leads to lack of understanding of water } \\
\text { issues in communities } \\
\text { Results in locals having a sense of not } \\
\text { being listened to by government } \\
\text { Exacerbates poor relationships and } \\
\text { confusion about roles and responsibilities }\end{array}$ \\
\hline GA3 Poor housing maintenance & $\begin{array}{l}\text { - Bureaucratic process, unclear roles between } \\
\text { housing and water agencies } \\
\text { Existing contractual arrangements } \\
\text { lack oversight }\end{array}$ & $\begin{array}{l}\text { - Maintenance regime poorly coordinated leading } \\
\text { to long repair time of leaks/equipment } \\
\text { - } \quad \text { Results in poor water efficiency } \\
\text { - } \quad \text { Exacerbated by rigid and convoluted processes } \\
\text { and requirements }\end{array}$ & $\begin{array}{l}\text { - Maintenance processes are cumbersome } \\
\text { and discourage residents from } \\
\text { reporting leaks } \\
\text { - Poor maintenance can lead to impression } \\
\text { that locals do not take care of their homes }\end{array}$ \\
\hline \multicolumn{4}{|c|}{ Economic and Financial (EF) } \\
\hline $\begin{array}{l}\text { EF1 Community dependency on } \\
\text { government for local } \\
\text { economic activity }\end{array}$ & $\begin{array}{l}\text { - Government generates most economic activity } \\
\text { in remote Indigenous communities }\end{array}$ & $\begin{array}{l}\text { Power imbalance between government and } \\
\text { communities constrains dialogue and } \\
\text { successful collaboration }\end{array}$ & $\begin{array}{l}\text { - } \quad \text { Community expectation of government to } \\
\text { solve problems perpetuates passivity } \\
\text { - } \quad \text { Can result in disenfranchisement }\end{array}$ \\
\hline $\begin{array}{l}\text { EF2 Short-term funding cycles, } \\
\text { under-funding, and preference of } \\
\text { capital investments within a } \\
\text { politicized funding environment }\end{array}$ & $\begin{array}{l}\text { - Little funding available for long-term } \\
\text { community relationship and capacity building } \\
\text { - Capital expenditure preferred over O\&M* } \\
\text { - } \quad \text { CSO + lacks criteria to drive } \\
\text { sustainable outcomes }\end{array}$ & $\begin{array}{l}\text { - Under-funded projects often set up to fail, } \\
\text { reinforcing "technical solutions" approach } \\
\text { "Core business" focus on infrastructure at expense } \\
\text { of sustainable social innovations } \\
\text { - Collaborative processes require relationship } \\
\text { building, leading to upfront investment in time } \\
\text { and money }\end{array}$ & $\begin{array}{ll}\text { - } & \text { Disincentivizes innovative methods } \\
\text { - } & \text { Missed opportunities to design locally } \\
\text { relevant services } \\
\text { - } \quad \text { Communities receive } \\
\text { inconsistent messages }\end{array}$ \\
\hline
\end{tabular}


Table A3. Cont.

\begin{tabular}{|c|c|c|c|}
\hline Barrier & Regional, Cross-Community, and Institutional & Local Community Projects/Program & Individual Individual/Household or Groups \\
\hline $\begin{array}{l}\text { EF3 Remote water supplies not } \\
\text { financially self-sustaining }\end{array}$ & $\begin{array}{l}\text { Financially sustainable water systems unlikely } \\
\text { to be achieved with no way to recoup costs }\end{array}$ & $\begin{array}{l}\text { Continued investment in reactive projects as } \\
\text { strategic, long-term funding is limited }\end{array}$ & $\begin{array}{l}\text { Households do not pay for water; } \\
\text { "invisible" means little incentive exists to } \\
\text { actively manage }\end{array}$ \\
\hline \multicolumn{4}{|c|}{ Data and Information (DI) } \\
\hline $\begin{array}{l}\text { DI1 Poor data and } \\
\text { management processes }\end{array}$ & $\begin{array}{ll}\text { - } & \text { Poor quality data, lack of coordination of } \\
\text { measurement and storage prevents } \\
\text { effective management }\end{array}$ & $\begin{array}{l}\text { - Convoluted processes to diagnose issues-split } \\
\text { between who collects, analyzes, and acts on } \\
\text { data/information collected } \\
\text { Assumptions about how and why water is used } \\
\text { can be inaccurate }\end{array}$ & $\begin{array}{l}\text { - Gap in knowledge of water use at } \\
\text { household level } \\
\text { - Lack of engagement of community } \\
\text { members prevents understanding of } \\
\text { household water use and practices } \\
\text { - } \quad \begin{array}{l}\text { In-community staff can lack } \\
\text { skills/knowledge of how to measure or } \\
\text { interpret key water data, perpetuating } \\
\text { dependence on external inputs }\end{array} \\
\end{array}$ \\
\hline $\begin{array}{l}\text { DI2 Lack of local and } \\
\text { disaggregated data on water } \\
\text { sources and consumption }\end{array}$ & $\begin{array}{l}\text { Little standardized or strategic data capture to } \\
\text { inform planning or targets, particularly with } \\
\text { smaller water providers }\end{array}$ & $\begin{array}{l}\text { - Only a small number of communities use smart } \\
\text { meters for water } \\
\text { - High mobility and variability in and across } \\
\text { Indigenous communities hinders prediction and } \\
\text { forward planning }\end{array}$ & $\begin{array}{l}\text { Lack of disaggregated household level } \\
\text { water data prevents feedback and capacity } \\
\text { building to community members to } \\
\text { enable self-management }\end{array}$ \\
\hline \multicolumn{4}{|c|}{ Capacity/Skills, Education, and Employment (CA) } \\
\hline $\begin{array}{l}\text { CA1 Lack of capacity in water } \\
\text { service provider organizations for } \\
\text { collaborative approaches }\end{array}$ & $\begin{array}{l}\text { Leaders can be unaware of their } \\
\text { responsibilities and legal obligations to meet } \\
\text { safe, reliable water supplies, or lack skills to } \\
\text { do so }\end{array}$ & $\begin{array}{l}\text { Water staff are technically trained, skewing } \\
\text { toward technical projects rather evidence-based } \\
\text { community engagement projects }\end{array}$ & $\begin{array}{l}\text { Community members do not have } \\
\text { accessible information to proactively } \\
\text { manage water }\end{array}$ \\
\hline $\begin{array}{l}\text { CA2 Lack of local skills, } \\
\text { awareness, and education in } \\
\text { water systems }\end{array}$ & $\begin{array}{l}\text { - Reliance on outside staff that have high } \\
\text { turnover rates constrains relationship building } \\
\text { and institutional learning }\end{array}$ & $\begin{array}{l}\text { Projects are often poorly designed, failing to build } \\
\text { awareness and education of community members } \\
\text { Engaging external expertise adds to project costs }\end{array}$ & $\begin{array}{l}\text { Water is a low priority in many } \\
\text { communities with limited technical } \\
\text { knowledge about water consumption, } \\
\text { quality, conservation, etc. } \\
\text { Community water staff can be overloaded, } \\
\text { with little support as few locals have } \\
\text { relevant skills or qualifications }\end{array}$ \\
\hline
\end{tabular}


Table A3. Cont.

\begin{tabular}{|c|c|c|c|}
\hline Barrier & Regional, Cross-Community, and Institutional & Local Community Projects/Program & Individual Individual/Household or Groups \\
\hline $\begin{array}{l}\text { CA3 Lack of pathways to local } \\
\text { employment in water sector }\end{array}$ & $\begin{array}{l}\text { - Water governance structures overlook } \\
\text { opportunities to build community capacity } \\
\text { through employment } \\
\text { Water-related jobs require skills training that } \\
\text { occurs outside of communities } \\
\text { - } \quad \begin{array}{l}\text { Small market for employing local people in } \\
\text { remote regions reliant on government }\end{array} \\
\text { - } \quad \begin{array}{l}\text { Existing schemes, e.g., CDP scheme } \\
\text { to facilitate local employment in water }\end{array}\end{array}$ & $\begin{array}{l}\text { - Lack of resources allocated to train local } \\
\text { community members } \\
\text { Reliance on external staff and contractors (fly in, } \\
\text { fly out) hinders relationship building and } \\
\text { increases project costs } \\
\text { - Lacking community presence and regular } \\
\text { communication, projects fail to engage } \\
\text { community members } \\
\text { Reliance on volunteers is a risk to ongoing project } \\
\text { success and social learning }\end{array}$ & $\begin{array}{l}\text { - Water-related training often happens } \\
\text { outside of communities hindering } \\
\text { local participation } \\
\text { Training can be poorly delivered leaving } \\
\text { trainees without practical skills } \\
\text { CDP lacks flexibility to facilitate casual } \\
\text { labor at cost-effective rates, financial } \\
\text { penalties can disincentivize full-time work }\end{array}$ \\
\hline \multicolumn{4}{|c|}{ Cultural Values and Norms (CV) } \\
\hline $\begin{array}{l}\text { CV1 Indigenous cultural and } \\
\text { social norms, protocols, and } \\
\text { values are diverse within and } \\
\text { across communities }\end{array}$ & $\begin{array}{l}\text { Communities are diverse, with local politics } \\
\text { playing a role in decisions; assumptions that } \\
\text { all views are represented by leadership } \\
\text { are false }\end{array}$ & $\begin{array}{l}\text { - } \quad \text { One-size-fits-all" project and community } \\
\text { engagement design ignores diversity and } \\
\text { alienates community segments } \\
\text { Default projects in English can exclude some } \\
\text { community members-often second or } \\
\text { third language } \\
\text { - Different Western and Indigenous meanings and } \\
\text { interpretation not considered in project } \\
\text { design elements }\end{array}$ & 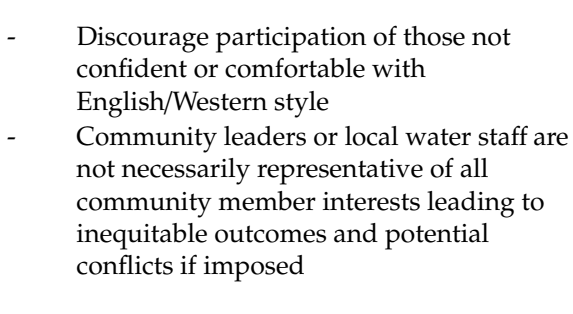 \\
\hline $\begin{array}{l}\text { CV2 Service provider limited } \\
\text { understanding of Indigenous } \\
\text { cultural protocols, values, and } \\
\text { norms }\end{array}$ & $\begin{array}{l}\text { - Colonial mindset being perpetuated through } \\
\text { management processes } \\
\text { - Limited cultural awareness capacity in } \\
\text { service providers }\end{array}$ & $\begin{array}{l}\text { Decisions about water infrastructure and } \\
\text { management lack local perspectives } \\
\text { - Lack of awareness and respect for local } \\
\text { knowledge, custom and protocols } \\
\text { - Western and Indigenous timelines and approaches } \\
\text { to deliberation challenge shared learning } \\
\text { - Engagement typically assume normative position } \\
\text { on increased participation as "good", not the case }\end{array}$ & $\begin{array}{l}\text { - Community members do not feel listened } \\
\text { to or valued in decisions that affect them } \\
\text { - Leads to "participation fatigue" and } \\
\text { disengagement, low trust, tension, or } \\
\text { even conflict } \\
\text { Limited cultural awareness training is } \\
\text { conducted in water provider and } \\
\text { related agencies }\end{array}$ \\
\hline
\end{tabular}

O\&M—operation and maintenance; + CSO—community service obligation; ^ CDP scheme (also known as CDEP)—the Commonwealth Development and Employment Program that seeks to find pathways to employment for locals in regional and remote areas. 


\section{References}

1. United Nations. SDG 6: Clean Water and Sanitation. Sustainable Development Goals: 17 Goals To Transform Our World. 2015. Available online: https://www.un.org/sustainabledevelopment/water-and-sanitation/ (accessed on 12 March 2018).

2. Jackson, S.; Barber, M. Recognition of indigenous water values in Australia's Northern Territory: Current progress and ongoing challenges for social justice in water planning. Plan. Theory Pract. 2013, 14, 435-454. [CrossRef]

3. UNDESA. State of the World's Indigenous Peoples ST/ESA/328; United Nations Department of Economic and Social Affairs United Nations Publication: New York, NY, USA, 2009.

4. UNDESA. State of the World's Indigenous Peoples: Indigenous Peoples' Access to Health Services; United Nations Publications: New York, NY, USA, 2014.

5. Jackson, S. Compartmentalising Culture: The articulation and consideration of Indigenous values in water resource management. Aust. Geogr. 2006, 37, 19-31. [CrossRef]

6. Kim, A.; Barbara, C.; Margaret, H.B. Carriers of water: Aboriginal women's experiences, relationships, and reflections. J. Clean. Prod. 2013, 60, 11-17. [CrossRef]

7. Tinoco, M.; Cortobius, M.; Grajales, M.D.; Kjellén, M. Water Co-operation between Cultures: Partnerships with Indigenous Peoples for Sustainable Water and Sanitation Services. Aquat. Procedia 2014, 2, 55-62. [CrossRef]

8. Walker, B.; Porter, D.; Marsh, I. Fixing the Hole in Australia's Heartland: How Government needs to Work in Remote Australia; Alice Srpings: Desert Knowledge, Australia, 2012.

9. Hawke, S.M. Water literacy: An "other wise", active and cross-cultural approach to pedagogy, sustainability and human rights. Contin. Media Cult. Stud. 2012, 2, 235-247. [CrossRef]

10. Pahl-Wostl, C. The implications of complexity for integrated resources management. Environ. Model. Softw. 2007, 22, 561-569. [CrossRef]

11. Xie, M. Integrated Water Resources Management (IWRM)-Introduction to Principles and Practices. Presented at the Africa Regional Workshop on IWRM, Nairobi, Kenya, 13 October 2006; pp. 1-15. Available online: http://pacificwater.org/userfiles/file/IWRM/Toolboxes/introductiontoiwrm/IWRMIntroduction.pdf (accessed on 15 April 2019).

12. Checkland, P. Systems Thinking, Systems Practice; John Wiley \& Sons Ltd.: Chichester, UK, 1993.

13. Tesoriero, F. Community Development: Community-Based Alternatives In An Age of Globalisation; Pearson Australia: Frenchs Forest, NSW, Australia, 2010; p. 344.

14. Innes, J.E.; Booher, D.E. Collaborative rationality as a strategy for working with wicked problems. Landsc. Urban Plan. 2016, 154, 8-10. [CrossRef]

15. Bowie, R. Indigenous self-governance and the deployment of knowledge in collaborative environmental management in Canada. J. Can. Stud. 2013, 47, 91-121. [CrossRef]

16. Escott, H.; Beavis, S.; Reeves, A. Incentives and constraints to Indigenous engagement in water management. Land Use Policy 2015, 49, 382-393. [CrossRef]

17. Jackson, S.; Tan, P.L.; Mooney, C.; Hoverman, S.; White, I. Principles and guidelines for good practice in Indigenous engagement in water planning. J. Hydrol. 2012, 474, 57-65. [CrossRef]

18. Hunt, J. Engaging with Indigenous Australia-Exploring the Conditions for Effective Relationships with Aboriginal and Torres Strait Islander Communities: Issues Paper no. 5 Produced for the Closing the Gap Clearinghouse. Closing the Gap Clearinghouse. 2013. Available online: www.aihw.gov.au/closingthegap (accessed on 5 April 2019).

19. Zurba, M.; Ross, H.; Izurieta, A.; Rist, P.; Bock, E.; Berkes, F. Building co-management as a process: Problem solving through partnerships in Aboriginal Country, Australia. Environ. Manag. 2012, 49, 1130-1142. [CrossRef] [PubMed]

20. Innes, J.E.; Booher, D.E. Planning With Complexity: An Introduction to Collaborative Rationality for Public Policy; Routledge: Abingdon, Oxon, UK, 2010; pp. 1-237.

21. Jackson, M.; Stewart, R.; Fielding, K.; Cochrane, J.; Beal, C. Collaborating for Sustainable Water and Energy Management: Assessment and Categorisation of Indigenous Involvement in Remote Australian Communities. Sustainability 2019, 11, 427. [CrossRef] 
22. Tawfik, S. Pursuing Sustainable Urban Water Management Through Co-Governance: A Case Study of Marrickville Council; Cooperative Research Centre for Water Sensitive Cities Ltd.: Clayton, VIC, Australia, 2016; pp. 1-52.

23. Hill, R.; Grant, C.; George, M.; Robinson, C.J.; Jackson, S.; Abel, N. A Typology of Indigenous Engagement in Australian Environmental Management: Implications for Knowledge Integration and Social- ecological System Sustainability. Ecol. Soc. 2012, 17, 23. [CrossRef]

24. Innes, J.E.; Connick, S.; Booher, D. Informality as a Planning Strategy: Collaborative Water Management in the CAL. Water Manag. 2007, 73, 195-210.

25. Reed, M.S. Stakeholder participation for environmental management: A literature review. Biol. Conserv. 2008, 141, 2417-2431. [CrossRef]

26. Hoverman, S.; Ayre, M. Methods and approaches to support Indigenous water planning: An example from the Tiwi Islands, Northern Territory, Australia. J. Hydrol. 2012, 474, 47-56. [CrossRef]

27. Pahl-Wostl, C.; Lebel, L.; Knieper, C.; Nikitina, E. From applying panaceas to mastering complexity: Toward adaptive water governance in river basins. Environ. Sci. Policy 2012, 23, 24-34. [CrossRef]

28. Capra, F. The Web of Life; Anchor Books, Doubleday: New York, NY, USA, 1996.

29. Robins, L.; Burt, T.P.; Bracken, L.J.; Boardman, J.; Thompson, D.B.A. Making water policy work in the United Kingdom: A case study of practical approaches to strengthening complex, multi-tiered systems of water governance. Environ. Sci. Policy 2017, 71, 41-55. [CrossRef]

30. Zeitoun, M.; Lankford, B.; Krueger, T.; Forsyth, T.; Carter, R.; Hoekstra, A.Y.; Taylor, R.; Varis, O.; Cleaver, F.; Boelens, R.; et al. Reductionist and integrative research approaches to complex water security policy challenges. Glob. Environ. Chang. 2016, 39, 143-154. [CrossRef]

31. Willis, C.D.; Mitton, C.; Gordon, J.; Best, A. System tools for system change. BMJ Qual. Saf. 2012, 21, 250-262. Available online: http://qualitysafety.bmj.com/content/21/3/250.abstract (accessed on 30 June 2019). [CrossRef]

32. Beard, N.; Climie, K.; Vervetjes, E.; Saunders, P.; Gerardi, W. Business Case and Implementation of Efficiency-NT Indigenous Communities. In Proceedings of the OzWater13 Conference, Perth, Australia, 7-9 May 2013.

33. Grey-Gardner, R. Remote Community Water Management; DKCRC Research Report 27; Alice Springs: Northern Territory, Australia, 2008. Available online: http://www.desertknowledgecrc.com.au/resource/DKCRCReport-27-Remote-Community-Water-ManagementWEB2.pdf (accessed on 28 May 2018).

34. Frank, F.; Smith, A. Community Development and Partnerships: A Handbook for Building Community Partnerships; Curtin University of Technology: Bentley, WA, Australia, 2006.

35. Beard, N. Water Proofing Homelands: Integrating Approaches for Small Water Supply Reliability. In Centre for Appropriate Technology Paper; Alice Springs: Northern Territory, Australia, 2006.

36. Commonwealth of Australia. National Partnership Agreement on Remote Service Delivery Evaluation 2013; Commonwealth Government, 2014. Available online: https://www.pmc.gov.au/resource-centre/ indigenous-affairs/national-partnership-agreement-remote-service-delivery-evaluation-2013 (accessed on 15 September 2018).

37. Yuen, E. Water Consumption Patterns in Australian Aboriginal Communities. Murdoch University. 2014. Available online: http://researchrepository.murdoch.edu.au/id/eprint/419/1/01Front.pdf (accessed on 27 June 2018).

38. Duncan. Productivity Commission Final Report. Water: Journal of the Australian Water Association). 2011, 28. Available online: http://www.awa.asn.au/AWA_MBRR/Publications/Water_eJournal/AWA_ MBRR/Publications/AWA_Water_e-journal.aspx?hkey=f5db50da-a42d-460e-a603-4259ae6b0528 (accessed on 24 April 2018).

39. Beal, C.D.; Jackson, M.; Stewart, R.A.; Rayment, C.; Miller, A. Identifying and understanding the drivers of high water consumption in remote Australian Aboriginal and Torres Strait Island communities. J. Clean. Prod. 2018, 172, 2425-2434. [CrossRef]

40. Davidson-Hunt, I.J.; O'Flaherty, R.M. Researchers, Indigenous Peoples, and Place-Based Learning Communities. Soc. Nat. Resour. 2007, 20, 291-305. [CrossRef]

41. Chaffin, B.; Garmestani, A.S.; Gunderson, L.; Benson, M.H.; Angeler, D.G.; Arnold, C.A.; Cosens, B.; Craig, R.K.; Ruhl, J.B.; Allen, C.R. Transformative Environmental Governance. Annu. Rev. Environ. Resour. 2016, 41, 399-423. [CrossRef] 
42. Australian Bureau of Statistics. 3238.0.55.001-Estimates of Aboriginal and Torres Strait Islander Australians, June 2016. Australian Bureau of Statistics: Canberra, ACT, Australia. 2018. Available online: https://www. abs.gov.au/AUSSTATS/abs@.nsf/Lookup/3238.0.55.001Main+Features1June2016?OpenDocument (accessed on 18 September 2018).

43. Marmion, D.; Obata, K.; Troy, J. Community, Identity, Wellbeing: The Report of the Second National Indigenous Languages Survey; Australian Institute of Aboriginal and Torres Strait Islander Studies (AIATSIS): Canberra, ACT, Australia, 2014.

44. Australian Bureau of Statistics. Estimates of Aboriginal and Torres Strait Islander Australians June 2011; Australian Bureau of Statistics: Canberra, ACT, Australia, 2013.

45. Miles, K.; Byrnes, J.; Bannon, K. Review of Regional Water Quality \& Security: Review \& Reform Strategy Volume 1, Prepared for Infrastructure Australia. 2010. Volume 1. Available online: https://infrastructureaustralia.gov.au/policypublications/publications/files/Review_of_RegionalWaterQuality_and_Security_Volume1_251010.pdf (accessed on 27 February 2019).

46. Queensland Productivity Commission. Service Delivery in Remote and Discrete Aboriginal and Torres Strait Islander Communities: Draft Report. 2017. Available online: https://www.qpc.qld.gov.au/inquiries/servicedelivery-in-queenslands-remote-and-discrete-indigenous-communities/ (accessed on 27 February 2019).

47. Anda, M.; Dallas, S. Delivering Essential Services in Desert Indigeneous Settlements. In Proceedings of the Building for Diversity National Housing Conference 2005; 2005; pp. 305-315. Available online: http://www.nationalhousingconference.org.au/article.asp?ContentID=nhc_2005\#proceedings (accessed on 27 February 2019).

48. Beal, C.D.; Gurung, T.R.; Stewart, R.A. Modelling the impacts of water efficient technologies on energy intensive water systems in remote and isolated communities. Clean Technol. Environ. Policy 2016, 18, 1713-1723. [CrossRef]

49. WHO. Water Safety Planning for Small Community Water Supplies; World Health Organization: Geneva, Switzerland, 2012.

50. Molle, F.; Mollinga, P.P.; Meinzen-Dick, R. Water, politics and development: Introducing water alternatives. Water Altern. 2008, 1, 1-6.

51. Hall, N.; Barbosa, M.C.; Currie, D.; Dean, A.J.; Head, B.; Hill, P.S.; Naylor, S.; Reid, S.; Selvey, L.; Willis, J. Water, Sanitation and Hygiene in Remote Indigenous Australia: A Scan of Priorities; Global Change Institute Discussion Paper: Water for Equity and Wellbeing Series; The University of Queensland: Brisbane, QLD, Australia, 2017.

52. CSIRO and Bureau of Meteorology. State of the Climate: 2016. 2016. (State of the Climate Reports). Available online: http://www.bom.gov.au/state-of-the-climate/State-of-the-Climate-2016.pdf (accessed on 21 January 2018).

53. Australian Bureau of Statistics. Community Housing and Infrastructure Needs Survey: Data Dictionary, Australia (Reissue); Australian Bureau of Statistics: Canberra, ACT, Australia, 2007.

54. Australian Government Department of Prime Minister and Cabinet. Closing the Gap Report 2019. 2019. Available online: https://ctgreport.pmc.gov.au/sites/default/files/ctg-report-2019.pdf?a=1 (accessed on 20 October 2019).

55. Productivity Commission. Overcoming Indigenous Disadvantage: Key Indicators 2016; Produced by the Productivity Commission for the Steering Committee for the Review of Government Service Provision; Productivity Commission: Canberra, ACT, Australia, 2016; p. 791.

56. Howitt, R. Sustainable indigenous futures in remote Indigenous areas: Relationships, processes and failed state approaches. GeoJournal 2012, 77, 817-828. [CrossRef]

57. Vogl, A.L.; Goldstein, J.H.; Daily, G.C.; Vira, B.; Bremer, L.; McDonald, R.I.; Shemie, D.; Tellman, B.; Cassin, J. Mainstreaming investments in watershed services to enhance water security: Barriers and opportunities. Environ. Sci. Policy 2017, 75, 19-27. [CrossRef]

58. Sofoulis, Z. Big Water, Everyday Water: A Sociotechnical Perspective. Contin. Media Cult.Stud. 2005, 19, 445-463. [CrossRef]

59. Hutchings, P. Community management or coproduction? The role of state and citizens in rural water service delivery in India. Water Altern. 2018, 11, 357-374.

60. Taylor, B.; de Loë, R.C.; Bjornlund, H. Evaluating knowledge production in collaborative water governance. Water Altern. 2012, 6, 42-66. 
61. Lubell, M.; Leach, W.D.; Sabatier, P.A. Collaborative Watershed Partnerships in the Epoch of Sustainability. In Toward Sustainable Communities: Transition and Transformations in Environmental Policy, 2nd ed.; Mazmanian, D.A., Kraft, M.E., Eds.; The MIT Press: Cambridge, MA, USA, 2009; pp. 255-288.

62. Brisbois, M.C.; de Loë, R.C. Power in Collaborative Approaches to Governance for Water: A Systematic Review. Soc. Nat. Resour. 2016, 29, 775-790. [CrossRef]

63. Von Der Porten, S.; De Loë, R.C. Geoforum Collaborative approaches to governance for water and Indigenous peoples: A case study from British Columbia, Canada. Geoforum. 2013, 50, 149-160. [CrossRef]

64. Emery, M.E.; Flora, C. Spiraling-Up: Mapping Community Transformation with Community Capitals Framework. Community Dev. 2006, 37, 19-35. [CrossRef]

65. Stefanelli, R.; Castleden, H.; Cunsolo, A.; Martin, D.; Harper, S.L.; Hart, C. Canadian and Australian researchers' perspectives on promising practices for implementing indigenous and Western knowledge systems in water research and management. Water Policy 2017, 19, 1063-1080. [CrossRef]

66. Diver, S. Negotiating Indigenous knowledge at the science policy-interface: Insights from the Xáxli'p Community Forest. Environ. Sci. Policy 2017, 73, 1-11. [CrossRef]

67. Westoby, P.; Dowling, G. Dialogical Community Development: With Depth, Solidarity and Hospitality; Tafina Press: West End, QLD, Australia, 2009; p. 227.

68. Moran, M.; Elvin, R. Coping with Complexity: Adaptive Governance in Desert Australia. GeoJournal 2014, 74, 415-428. [CrossRef]

69. Kwiatkowski, R.E. Indigenous community based participatory research and health impact assessment: A Canadian example. Environ. Impact Assess. Rev. 2011, 31, 445-450. [CrossRef]

70. FaHCSIA. National Indigenous Infrastructure Guide; Australian Government Department of Families, Housing, Community Services and Indigenous Affairs: Canberra, Australia, 2010. Available online: https://cfat.org.au/ national-indigenous-infrastructure-guide (accessed on 21 January 2018).

71. Hunt, J. Engagement with Indigenous Communities in Key Sectors; Resource Sheet No. 23, Produced for the Closing the Gap Clearinghouse; Australian Institute of Health and Welfare and the Australian Institute of Family Studies: Canberra, Australia, 2013.

72. Brown, R.R.; Farrelly, M.A. Delivering sustainable urban water management: A review of the hurdles we face. Water Sci. Technol. 2009, 59, 839-846. [CrossRef]

73. Dodson, M.; Smith, D.E. Governance for Sustainable Development: Strategic Issues and Principles for Indigenous Australian Communities; Centre for Aboriginal Economic Policy Research (CAEPR), The Australian National University: Canberra, Australia, 2003; pp. 1-25.

74. Australian Healthcare Association. Chapter 9 Findings: Effectiveness-Enablers and Barriers. In Evaluation of the National Suicide Prevention Project (NSPP) Activities. 2013. Available online: https://www.health.gov. au/internet/main/publishing.nsf/Content/4FD5C304C536BDE3CA257CAF0017ADE9/\$File/9.pdf (accessed on 15 May 2019).

75. Moran, M. The Intercultural Practice of Local Governance in an Aboriginal Settlement in Australia. Hum. Organ. 2010, 69, 65-74. [CrossRef]

76. Buergelt, P.T.; Maypilama, E.L.; McPhee, J.; Dhurrkay, G.; Nirrpuranydji, S.; Mänydjurrpuy, S.; Wunungmurra, M.; Skinner, T.; Lowell, A.; Moss, S. Working Together with Remote Indigenous Communities to Facilitate Adapting to Using Energy Wisely: Barriers and Enablers. Energy Procedia 2017, 121, 262-269. [CrossRef]

77. Pearce, M.; Willis, E.; Jenkin, T. Aboriginal perceptions of incompatibility of location, lifestyle and water resources. In Proceedings of the 30th WEDC International Conference, Vientiane, Laos, 25-29 October 2004; pp. 384-391.

78. Willis, E.; Pearce, M.; Mccarthy, C.; Ryan, F.; Wadham, B. Indigenous Responses to Water Policymaking in Australia. Development 2008, 51, 418-424. Available online: http://proquest.umi.com/pqdweb?did= $1533862091 \& F m t=7 \&$ clientId=12520\&RQT=309\&VName=PQD (accessed on 27 February 2019). [CrossRef]

79. Watson, N.; Shrubsole, D.; Mitchell, B. Governance arrangements for integrated water resources management in Ontario, Canada, and Oregon, USA: Evolution and lessons. Water 2019, 11, 663. [CrossRef]

80. Seeman, K.; Mclean, S.; Fiocco, P. A Gap to Close: A literature Review of Waste Management, Health, and Wellbeing in Rural and Remote Aboriginal and Torres Strait Islander communities. 2017. Report for the WasteAid; Centre for Design Innovation, Swinburne University of Technology: Melbourne, Australia, 2017. 
81. Denzin, N.K.; Lincoln, Y.S. Strategies of Qualitative Inquiry; Sage Publications, Inc.: Thousand Oaks, CA, USA, 2008.

82. Kleiner, A.; Roth, G. Field Manual for a Learning Historian Version 4.0 October 28. 1996. Available online: http://scholar.google.com/scholar?hl=en\&btnG=Search\&q=intitle:Field+Manual+for+a+Learning+ Historian\#0 (accessed on 15 May 2018).

83. Map of Australia-Discrete Indigenous Communities and the Australian Standard Geographical Classification Remoteness Structure 2006. Maps and Census Profiles, Australian Indigenous Geographical Classification 2006, map, cat. no. 4706.0.30.001; Australian Bureau of Statistics: Canberra, Australia, 2006.

84. Neuman, W.L. Social Research Methods: Qualitative and Quantitative Approaches, 7th ed.; Allyn \& Bacon: Boston, MA, USA, 2011.

85. Miller, J.; Glassner, B. The "Inside" and the "Outside": Finding Realities in Interviews. In Qualitative Research, 3rd ed.; Silverman, D., Ed.; SAGE Publications Ltd.: London, UK, 2011.

86. Saldaña, J. The Coding Manual for Qualitative Researchers; SAGE Publications Ltd.: London, UK, 2009.

87. Attride-Stirling, J. Thematic networks: An analytic tool for qualitative research. Qual. Res. 2001, 1, $385-405$. [CrossRef]

88. Beekhuyzen, J.; Nielsen, S.L.; von Hellens, L.A. The NVivo Looking Glass: Seeing the Data through the Analysis. In Proceedings of the 5th Conference on Qualitative Research in IT, Brisbane, Australia, 29-30 November 2010.

89. Charmaz, K. Constructing Grounded Theory, 2nd ed.; SAGE Publications: London, UK, 2014.

90. Dunstan, C.; Ross, K.; Ghiotto, N. Barriers to Demand Management: A Survey of Stakeholder Perceptions; Publisher: Sydney, Australia, 2011.

91. Howarth, C.; Monasterolo, I. Understanding barriers to decision making in the UK energy-food-water nexus: The added value of interdisciplinary approaches. Environ. Sci. Policy 2016, 61, 53-60. [CrossRef]

92. Kragt, M.E.; Dumbrell, N.P.; Blackmore, L. Motivations and barriers for Western Australian broad-acre farmers to adopt carbon farming. Environ. Sci. Policy 2017, 73, 115-123. [CrossRef]

93. Karlsson-Vinkhuyzen, S.; Boelee, E.; Cools, J.; van Hoof, L.; Hospes, O.; Kok, M.; Peerlings, J.; van Tatenhove, J.; Termeer, C.J.; Visseren-Hamakers, I.J. Identifying barriers and levers of biodiversity mainstreaming in four cases of transnational governance of land and water. Environ. Sci. Policy 2018, 85, 132-140. [CrossRef]

94. Feliciano, D.; Hunter, C.; Slee, B.; Smith, P. Climate change mitigation options in the rural land use sector: Stakeholders' perspectives on barriers, enablers and the role of policy in North East Scotland. Environ. Sci. Policy 2014, 44, 26-38. [CrossRef]

95. Sietz, D.; Boschütz, M.; Klein, R.J.T. Mainstreaming climate adaptation into development assistance: Rationale, institutional barriers and opportunities in Mozambique. Environ. Sci. Policy 2011, 14, 493-502. [CrossRef]

96. Martin, N.J.; Rice, J.L. Developing renewable energy supply in Queensland, Australia: A study of the barriers, targets, policies and actions. Renew. Energy 2012, 44, 119-127. [CrossRef]

97. Henderson, R.; Abrahams, J. Community Water Conservation Guide Program Guide; Power and Water Corporation: Winnellie, Australia, 2010.

98. Altman, J. The Indigenous hybrid economy: A realistic sustainable option for remote communities? Econ. Policy 2006, 35, 1-6.

99. Gray, D.; Wilson, M.; Allsop, S.; Saggers, S.; Wilkes, E.; Ober, C. Barriers and enablers to the provision of alcohol treatment among Aboriginal Australians: A thematic review of five research projects. Drug Alcohol Rev. 2014, 33, 482-490. [CrossRef] [PubMed]

100. Snijder, M.; Shakeshaft, A.; Wagemakers, A.; Stephens, A.; Calabria, B. A systematic review of studies evaluating Australian Indigenous community development projects: The extent of community participation, their methodological quality and their outcomes. BMC Public Health 2015, 15, 1-16. [CrossRef] [PubMed]

101. Moran, M.; Porter, D.; Bank, W. Reinventing the Governance of Public Finances in Remote Indigenous Australia. Aust. J. Public Adm. 2014, 73, 115-127. [CrossRef]

102. Moran, M. Serious Whitefella Stuff: When Solutions became the Problem in Indigenous Affiars; Melbourne University Press: Melbourne, VIC, Australia, 2016; p. 222.

103. Tan, P.; Jackson, S. Impossible dreaming-Does Australia' s water law and policy fulfill Indigenous aspirations? Environ. Plan. Law J. 2013, 10, 132-149.

104. Taylor, K.S.; Moggridge, B.J.; Poelina, A. Australian Indigenous Water Policy and the impacts of the ever-changing political cycle. Australas. J. Water Resour. 2017, 20, 132-147. [CrossRef] 
105. Bueren, M.; van Worland, T.; Svanberg, A.; Lassen, J. Working for Our Country: A Review of the Economic and Social Benefits of Indigenous Land and Sea Management. 2015. Available online: https://www. countryneedspeople.org.au/indigenous_rangers_in_parliament (accessed on 15 May 2019).

106. Beal, C.D.; Stewart, R.; Miller, A.; Rayment, C. Identifying the drivers of high water consumption in remote Australian Aboriginal and Torres Strait Island Communities using a participatory, mixed method design. J. Clean. Prod. 2017, in press.

107. Australian Bureau of Statistics. Cat. 3228.0 Estimates and Projections, Aboriginal and Torres Strait Islander Australians, 2001 to 2026; Australian Bureau of Statistics: Canberra, Australia, 2014.

108. Cortobius, M.; Jiménez, A.; Kjellén, M.; Le Deunff, H. Recommendations for an intercultural approach in rural water and sanitation projects with Indigenous peoples. In Proceedings of the International Indigenous Development Research Conference 2014 Proceedings, 25-28 November 2014. Available online: http://www. maramatanga.ac.nz/sites/default/files/IIDRC\%202014\%20Proceedings.pdf (accessed on 27 February 2019).

109. Tuhiwai-Smith, L. Decolonising Methodologies: Research and Indigenous Peoples; Zed Books Ltd.: London, UK; University of Otago Press: Dunedin, New Zealand, 2003.

110. United Nations. Transforming Our World: The 2030 Agenda for Sustainable Development; Resolution 70/1 adopted by the United Nations General Assembly on 25 September 2015; United Nations: Geneza, Switzerland, 2015.

(C) 2019 by the authors. Licensee MDPI, Basel, Switzerland. This article is an open access article distributed under the terms and conditions of the Creative Commons Attribution (CC BY) license (http://creativecommons.org/licenses/by/4.0/). 